Hydrol. Earth Syst. Sci. Discuss., 8, 4753-4788, 2011 www.hydrol-earth-syst-sci-discuss.net/8/4753/2011/ doi:10.5194/hessd-8-4753-2011

(C) Author(s) 2011. CC Attribution 3.0 License.
Hydrology and Earth System Sciences Discussions

\title{
Calculating the average natural recharge in large areas as a factor of their lithology and precipitation
}

\section{E. Sanz, I. Menéndez Pidal de Navascués, and C. Távara}

Departamento de Ingeniería y Morfología del Terreno, Escuela Técnica Superior de Ingenieros de Caminos, Canales y Puertos, Universidad Politécnica de Madrid, Madrid, Spain

Received: 1 February 2011 - Accepted: 2 February 2011 - Published: 13 May 2011

Correspondence to: E. Sanz (esanz@ caminos.upm.es)

Published by Copernicus Publications on behalf of the European Geosciences Union.

HESSD

$8,4753-4788,2011$

Calculating the average natural recharge in large areas

E. Sanz et al.

\section{Title Page}

Abstract Introduction

Conclusions

References

Tables

Figures

14

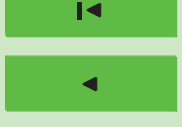

$\rightarrow$

Back

Close

Printer-friendly Version

Interactive Discussion 


\section{Abstract}

In an area as large as Spain, it is shown by statistical inference on a sample of 875 springs (with discharges greater than $10 \mathrm{I} \mathrm{s}^{-1}$ ), whose average flow, lithology and catchment areas are known, and which were grouped into regions of contrasting rainfall, 5 that the average annual recharge is a fixed fraction of annual rainfall for each lithology. Recharge rates have thus been established with respect to rainfall for six lithological groups of different permeability: sands, gravels and generally alluvial formations $8.3 \%$; conglomerates, 5.6\%; sandstones, $7.3 \%$; limestone and dolomite $34.3 \%$; marls, marly limestones, silts and clays, 3.3\%; and hard rocks, 1.3\%. Since Spain can be considered to be representative, given its large size and a highly varied lithology, topography and rainfall, these recharge rates with respect to rainfall are probably quasi-universal values, which can be used to estimate the average recharge or average groundwater resources of large regions in any part of the world (except in special cases such as areas that have permafrost). In any case, the recharge rates can be adapted for each region according to its particular characteristics. Rainfall and lithology data are abundant, and so the method can be widely used to calculate hydraulic balances. The method has been applied to the Duero basin in Spain and to other European countries (Portugal, Ireland and Italy), obtaining recharge results that are very similar to those calculated by other methods.

\section{Introduction}

The study of the natural recharge to aquifers is highly important since it is directly related to assessing groundwater resources and vulnerability of aquifers to pollution.

The factors that determine natural recharge are many, and include climate, geology and soil type (Kennet-Smith et al., 1994), land-use, hydrogeological characteristics and topography (Cherkauer and Ansari, 2005). When large regions are considered, some factors may diminish in importance while others increase. Over very large regions,
HESSD

$8,4753-4788,2011$

\section{Calculating the average natural recharge in large areas}

E. Sanz et al.

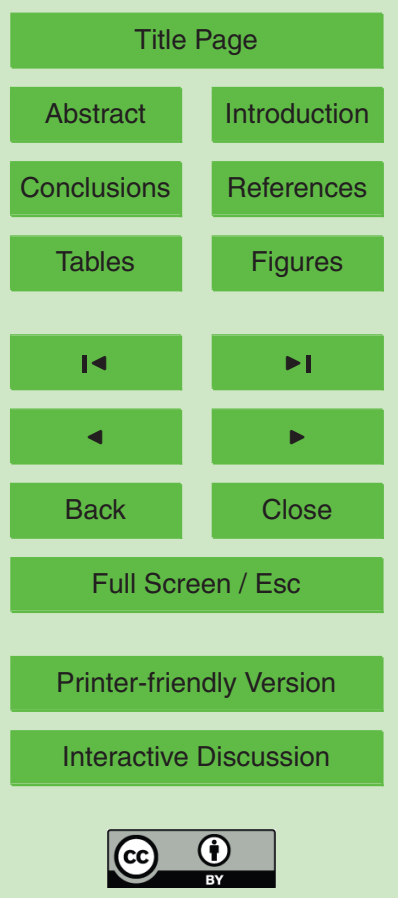


there may be three fundamental factors: precipitation, temperature (which determines evaporation, evapotranspiration and to certain extent the vegetation type), and the lithology of the outcrops.

The lithology is largely responsible for determining the recharge rate with respect to 5 the amount of precipitation. It is the decisive factor in determining the presence and magnitude of aquifers. Meanwhile, lithology and geology together tend largely to determine the nature and thickness of the dominant soil types in the regions. However, it is possible that other factors, such as topography, vegetation and land-use assume less importance, since over large regions, contrasting characteristics tend to compensate 10 one another and cancel each other out, for example, mountains-plains and forestscultivated areas.

Methods for calculating recharge are also numerous and varied and usually include uncertainties in the results obtained. This means that it is advisable to apply more than one method, if possible. In publications by Simmers (1988), Lerner (1997) and Scanlon et al. (2002), the different techniques for estimating recharge can be seen. The type of method and the spatial and time scales chosen depend on the purpose the calculation is to serve.

The method proposed here has as its goal the overall evaluation of groundwater resource of a country or large region, and this allows a wider range of both time and spatial scales. On the temporal scale, we refer to average annual values, while the spatial dimension may be specified as a more or less extensive territory, depending on the level of detail available for rainfall and lithological distribution. Working on this large scale, the conclusion is reached that the average annual recharge per unit area of a certain lithology is a constant fraction of the average annual rainfall in that area.

25 This conclusion has been reached by analysing observations for peninsular Spain and, although the results appear quite reliable, it would be advisable to confirm them in other areas.

The method does not aim to produce a spatial or cartographic distribution of recharge as its end result, but rather it obtains an average value for a large region in particular.

\section{5}

\section{HESSD}

8, 4753-4788, 2011

\section{Calculating the average natural recharge in large areas}

E. Sanz et al.

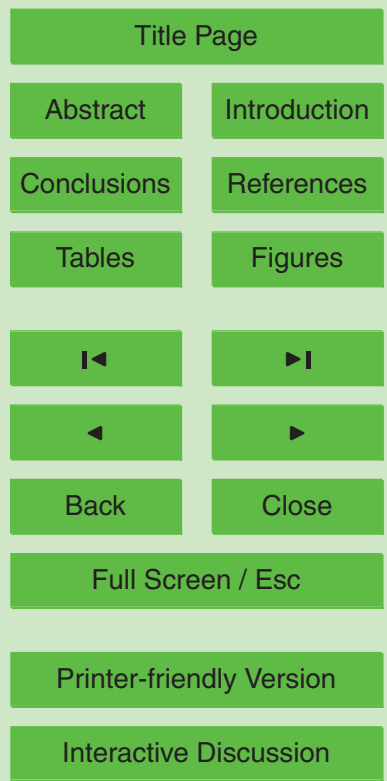


However, to calculate the latter requires the support of the spatial distribution of the outcrops and of precipitation, although these represent intermediate steps in the calculation. An understanding of the cartography was gained by referring to Dzhamalov and Zektser (1999) and WHYMAP (2008).

\section{$5 \quad 2$ Method}

\subsection{Generalisation of the distribution of the spring supplies according to discharge}

In previous work (Sanz, 1996, 2001), using a sample of 17305 springs distributed throughout peninsular Spain, obtained the distribution functions for flow, according to springflow discharge for each of the nine lithological groups into which the springs were classified. They conform to a generic function of the type:

$a_{i}(x)=k_{i} x^{-n i}$

where $a_{i}(x)$ represents the contribution of the springs of flow $x$; and $k_{i}$ and $n_{i}$ are parameters characteristic to each lithological group. The contribution of all the springs to each lithological group can be calculated by integrating $a_{i}(x)$ as follows:

$A_{i}=\int_{0.01}^{\max } k_{i} x^{-n i} d x=k_{i}\left|\frac{x^{1-n_{i}}}{1-n_{i}}\right|_{0.01}^{\max }$

where the integration limits extend from $0.01 \mathrm{Is}^{-1}=36 \mathrm{I} \mathrm{h}^{-1}$ as the lowest flow for a discharge to be considered a spring, to the maximum flow registered in each lithology. Once this integration is performed, it is seen that the contribution of the four lithologies that may be considered as impermeable (quartzite, slates, plutonic rocks and others) jointly contribute only $5.5 \%$ of the total, and therefore the number of lithological groups was reduced to five, thereby simplifying the estimates of recharge to a sample
HESSD

$8,4753-4788,2011$

Calculating the average natural recharge in large areas

E. Sanz et al.

Title Page

Abstract Introduction

Conclusions References

Tables Figures

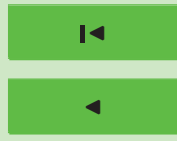

$\rightarrow 1$

Back

Close

Full Screen / Esc

Printer-friendly Version

Interactive Discussion 
of 875 springs, grouped into four areas of peninsular Spain with significantly varying rainfall (Fig. 1).

This aspect is applied later in this paper, but we will first demonstrate how these contributions can be identified from aquifers that discharge via springs with appreciable discharges of water. These contributions do not identify any diffuse discharges draining to seas, rivers or lakes. Table 1 shows the functions of contributions according to discharge and the annual value of these flows.

It may be assumed that, for a specific lithology, the function of contributions is always of type (Eq. 1), but it has different parameters depending on whether the lithology is 10 located in one place or another with different recharge. Moreover, it would be interesting to analyse the variation of these parameters as a function of the variables that can affect that recharge.

In several cases, it has been shown that, for a certain lithology, there is an excellent degree of correlation between aquifer recharge and the two variables of rainfall and air temperature. However, if referring to annual periods, the importance of rainfall is stands out, since the average temperature (and in consequence, the evapotranspiration, to a certain extent) hardly varies within a specific region.

Here, it is assumed that the greater or lesser natural recharge of a certain lithology (exponent $-n$ ) and its effects are revealed in the value of the parameter $k$. In addition to confirming these hypotheses in this study, it would also be interesting to verify them for other regions, since the most important conclusion would be that these functions could be applied to other countries or territories. In addition, to calculate the contributions, it would be sufficient to know the six lithological groups of the area and its rainfall. Not only could it be applied to other territories, but even within the same country, the annual variation could be calculated as a function of the rainfall for each year.

Since Spain has a very varied climate, we have tried, without looking further afield, to analyse how springs behave in four areas of different rainfall.
HESSD

8, 4753-4788, 2011

\section{Calculating the average natural recharge in large areas}

E. Sanz et al.

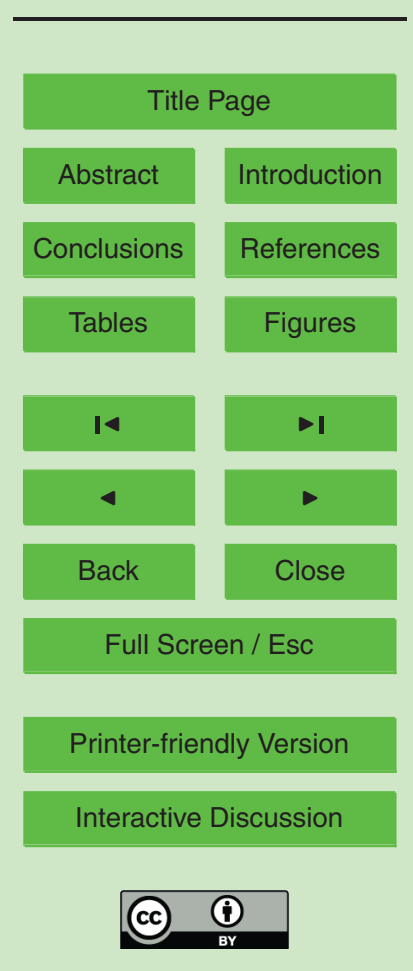




\subsection{Samples, lithology and geographic areas}

Let us consider some questions that focus the programming of this statistical inference:

- Since we are dealing with annual values and even annual averages, the assumed relationship between recharge and the rainfall and temperature values is reduced to rainfall alone. As explained above, the average annual temperature varies little and has only limited influence on the average annual recharge.

- The estimates of the functions of inflows according to discharges in each lithology were made in our previous studies, based on the number of springs with a discharge of more than $10 \mathrm{Is}^{-1}$. Among the reasons chosen for this threshold was that knowledge of these "large" springs was good and the sample could be considered complete; even within this group of springs, it was necessary to select those where the lithology of their recharge area was known.

- In the "remainder" lithological group (containing the lithologies considered only scarcely permeable), there is only one small spring (between $11 / \mathrm{s}^{-1}$ and $50 / \mathrm{s}^{-1}$ ), whilst for the other five lithological groups, the composition of the samples by the number of springs is as follows:

Limestones, Dolomites

664 springs

Alluvial sediments, sands and gravels 105 springs

Conglomerates

43 springs

Sandstones

23 springs

Marls, silts and clays

40 springs

Total

875 springs

- Since for each lithology, the aim is analyse the possible relationship between the inflow and the rainfall, the territory that corresponds to peninsular Spain was divided into four areas of differing average rainfall. Then the spring samples were assigned to each area. It was considered wise not to set up more than four areas 4758

\section{HESSD}

$8,4753-4788,2011$

Calculating the average natural recharge in large areas

E. Sanz et al.

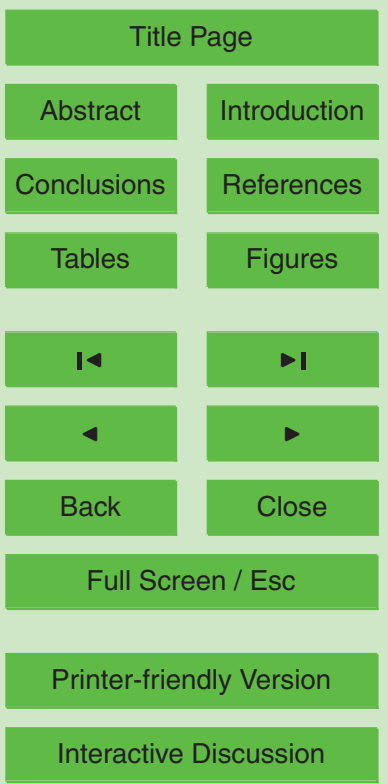


so as not to restrict excessively the number of springs in each lithology in each geographic area.

The following four geographic zones were established, each with significantly different mean annual rainfall:

Areas

Area 1: North (Cantabria and Galicia)

Area 2: Centre (Duero, Tajo, Ebro and Catalonian C. I.)

Area 3: South (Guadiana, Guadalquivir, South)

Area 4: Levante (Júcar and Segura)

Average Peninsular Spain

\subsection{Methodology and results of the parameter to be measured}

For each of the 875 springs in our sample, the following data were recorded: geographic area, discharge, lithology and surface lithology of the aquifer feeding the spring.

These data were first classified by geographic area, lithology, discharge and surface lithology, to obtain the number of springs in each group. The results, together with the calculation of their relative hydraulic contributions are shown in Table 2.

The results in Table 2 were then combined with the average rainfall in each geographic area to produce the data shown in Table 3 . This table reflects the recharge by 5 unit area $\left(\mathrm{I} \mathrm{m}^{-2}\right)$ compared to the average rainfall of the geographic area expressed in the same units. Thus, the percentage rainfall that has infiltrated is obtained for each lithology and geographic area.

The results obtained are highly significant since, the quotient derived for each lithological group shows hardly any differences between the various geographic areas. Infiltration of rainwater into the ground depends on, among other factors, the duration of the rainfall event, the moisture level of the soil, as expressed in Horton's law (1937). However, at a cumulative annual level, the percentage of natural recharge for a particular
HESSD

$8,4753-4788,2011$

Calculating the average natural recharge in large areas

E. Sanz et al.

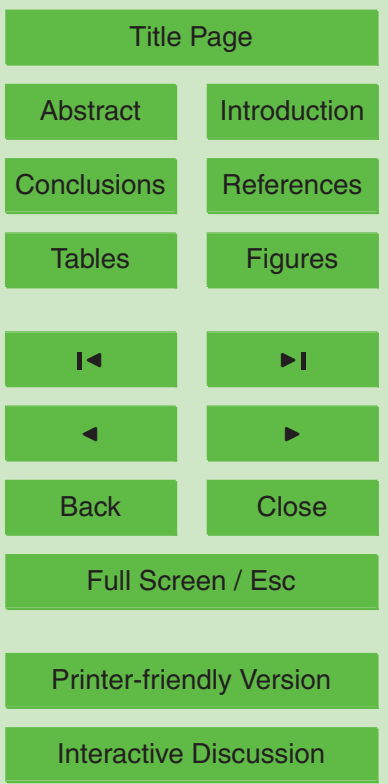


lithology is constant and is not influenced by the rainfall volume. The conclusion is reached that, provided the area considered is very large, the average annual recharge per surface unit of a certain lithology is a constant fraction of the average annual rainfall over this area.

5 Table 4 summarises the results in Table 3, together with the average, variance, standard deviation and relative error (\%). These relative values range between $23.5 \%$ for conglomerates and $5.1 \%$ for sandstones and they can be indicative of the margin of error that can be accepted when making estimates using this method of recharge calculation.

10 The average value for the five lithologies considered together, weighting each type by the volume of recharge, is $10.8 \%$. This value is close to that calculated for limestone, which is explained since most recharge occurs in this lithology.

These are indicative values as far as the error of these estimations is concerned, as other factors have to borne in mind, such as, e.g., the more reduced divisions for recording the rainfall variations instead of using average for a very large territory.

To be able to calculate the total recharge to peninsular Spain, there is a need to estimate the percent rainfall $\left(P_{i}\right)$ that goes to recharge the group of scarcely permeable outcrops, denominated "other lithologies". Considering the small recharge to the lithologies in this group, we can calculate an average recharge based on the data in 20 Table 1 for this group: area $168963 \mathrm{~km}^{2}$; recharge, $963.2 \mathrm{~h} \mathrm{~m}^{3}$. Hence, the contribution per unit area is (963.2/168963). $100=0.000057 \mathrm{~km}^{3} \mathrm{~h}^{-1} \mathrm{~m}^{-1}=5.7 \mathrm{~mm} \mathrm{~m} \mathrm{~m}^{-2}$. However, as the average rainfall is $687 \mathrm{~mm} \mathrm{~m}^{-2}$, the hydraulic contribution estimated before represents $0.83 \%$ of the rainfall.

\subsection{Applying the calculation to peninsular Spain}

25 The parameters used to establish the fraction of rainfall that is recharged form the basis of this calculation. In the absence of more accurate data, the annual national rainfall figure, i.e., $687 \mathrm{I} \mathrm{m}^{-2}$, is taken for all the lithological groups. Accordingly, the data shown in Table 5 is produced.

\section{HESSD}

$8,4753-4788,2011$

\section{Calculating the average natural recharge in large areas}

E. Sanz et al.

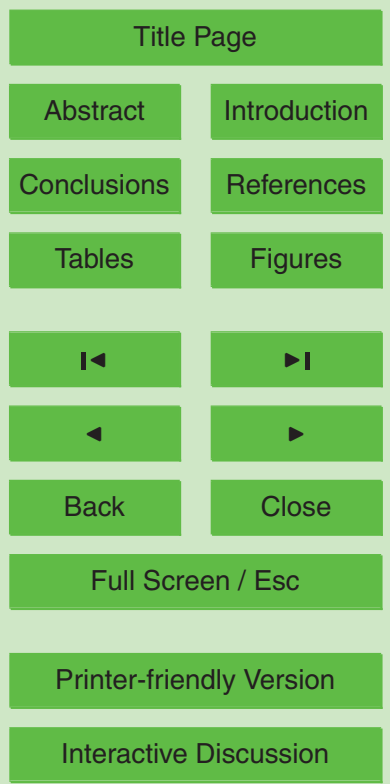


To calculate the contribution of the lithology, $i$, (in $\mathrm{h} \mathrm{m}^{3}$ ), the following formula has been used:

$A(i)=S_{i} \times$ precipitation $\times P_{i} \times 10^{-5}$

where $S_{i}$ is expressed in $\mathrm{km}^{2}, A(i)$ in $\mathrm{h} \mathrm{m}^{3}$, and rainfall in $\mathrm{Im}^{-2}$.

5 The results are quite similar to those in Table 1, which were obtained using the functions $a(x)$ of the contribution into each lithological type. In the overall calculation, the difference is less than $0.1 \%$. The greatest difference occurs in the "conglomerates" group, currently calculated to be $5.5 \%$ greater than that shown in Table 1.

\subsection{Adjustment of the results to represent the total natural recharge for Spain}

10 For any lithological type, it has already been highlighted that the mean annual recharge is a fixed fraction of the mean annual precipitation that falls over this lithology, independent of its value.

Up to this point in the study, this fixed fraction has been determined by calculating the flow in the emerging springs, which together equate to some $17326 \mathrm{hm}^{3} \mathrm{yr}^{-1}$ for 15 peninsular Spain. It has already been noted that the recharge on which previous calculations were based are summarised in Table 1, and that these were calculated from the mean annual flow of all springs, excluding diffuse flows to rivers, lakes and to the sea.

The mean annual recharge, expressed as a fraction of the groundwater component of river flow (from springs and diffuse discharges) and outflows to the sea, has been estimated for Spain as a whole for the period 1940/1940 to 1995/1996, as $28719 \mathrm{~h} \mathrm{~m}^{3} \mathrm{yr}^{-1}$ (MIMAM, 2000). This value is somewhat higher than the one calculated in the present article $\left(17326 \mathrm{~h} \mathrm{~m}^{3} \mathrm{yr}^{-1}\right)$. This leads to the supposition that the difference between these two figures $\left(11393 \mathrm{~h} \mathrm{~m}^{3} \mathrm{yr}^{-1}\right)$ corresponds to the diffuse discharges to rivers, lakes and to the sea.

Given that infiltration into each lithology is a fixed fraction of the annual rainfall, and assuming that the differences are maintained, new values of $P_{i}$ are obtained by

HESSD

$8,4753-4788,2011$

Calculating the average natural recharge in large areas

E. Sanz et al.

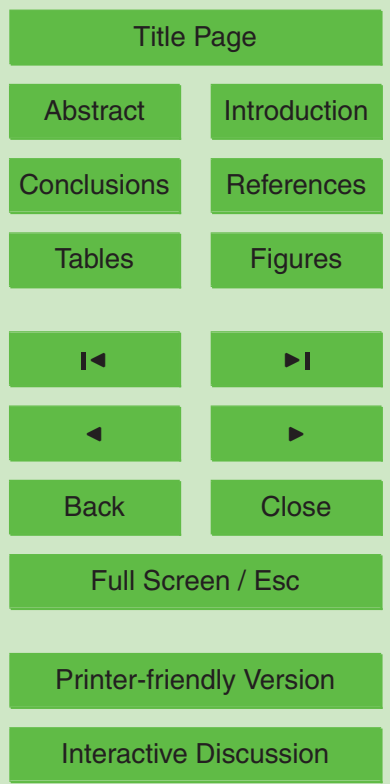


multiplying the earlier figure of total natural recharge by 1.66 , i.e., the ratio between the total natural recharge and spring discharge. Table 6 shows the factors $P_{i}$ (percentage of rainfall converted to recharge in a lithology, $i$, in an annual water balance) obtained on this basis, for peninsular Spain.

5 The recharge under a natural regime for a particular territory or country can be calculated using the formula:

Natural Recharge $\left(\mathrm{h} \mathrm{m}^{3}\right)=S_{i} \times P_{m} \times P_{i} \times 10^{-5}$

where $S_{i}$ expresses the surface of the lithology, $i$, in $\mathrm{km}^{2}$ and $P_{m}$, the average annual rainfall in $\mathrm{Im}^{-2}$.

The calculations highlight the limestone and dolomite lithologies. These occupy $15 \%$ of the total area, yet provide $61.4 \%$ of the total natural recharge to peninsular Spain. In contrast, the group of scarcely permeable rocks, which occupy $39 \%$ (more than a third of the territory), only provide $5.3 \%$ of the total recharge.

The factors, $P_{i}$ in Table 6 refer to peninsular Spain. Strictly speaking, their ideal 15 application would be in subregions of Spain itself, as in the case of the Duero catchment described in Sect. 3.1

It is clear that for small or medium-sized regions, the ratio of recharge destined for springflow/total recharge, can be highly variable. However, for large regions, thousands of $\mathrm{km}^{2}$ in extent, the ratio could resemble that estimated for Spain as a whole.

Spain is considered to be sufficiently large and representative, encompassing a wide variety of geology, lithology, rainfall, relief and vegetation. In addition, the total recharge is known with reasonable precision.

The proportion of recharge destined to springflow/total recharge (calculated using methods different to those used in our study) yields results for Portugal (1.58), Ireobtained for peninsular Spain (1.66).

These values are shown in Table 8 , which shows just the calculated recharge destined to springflow. It allows the $P_{i}$ for Spain to be used with certain guarantee.

HESSD

$8,4753-4788,2011$

\section{Calculating the average natural recharge in large areas}

E. Sanz et al.

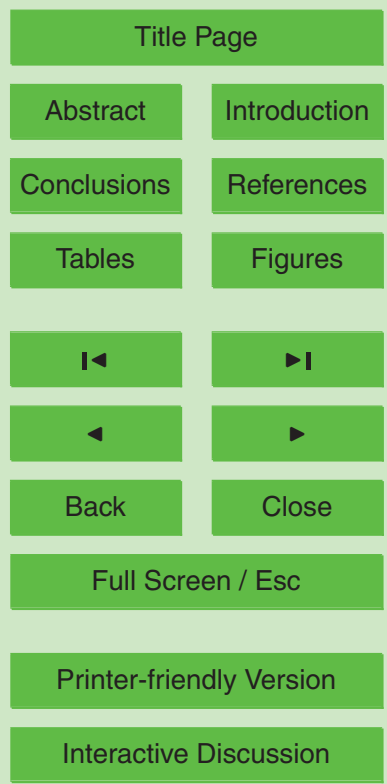


In any case, the proportionality would have to be adjusted to the total recharge in those regions where there are previous reliable calculations. Thus, rates of total recharge could be obtained for each region based on their different precipitation $\left(P_{i}\right)$.

During the period 1940-1990, the procedure followed in Spain to determine total 5 natural recharge was the distributed modelling of the basic components of the hydrological cycle on a countrywide scale (Estrela et al., 1999). This model makes use of the information recorded at gauging stations, weather data, and the characteristics of the aquifer examined. This conceptual, distributed hydrogeological model (which takes the spatial variability of all the hydrological data into account) can simulate the 10 mean monthly flows (natural regime) at any point in the country's hydrographic network by reproducing the essential processes of water transport in the different phases of the hydrological cycle. In each of the approximately 500000 cells of dimensions $1000 \times 1000 \mathrm{~m}$ into which Spain can be divided, it contemplates the principle of continuity and establishes the laws of transfer and sharing between the different storage 5 zones on monthly scale.

The model inputs used in the parent work were monthly rainfall and temperature data. Times of historic flow were taken as simulation or calibration points. Also taken into account were the maximum moisture storage capacity of the soil, the maximum infiltration capacity, and the recession coefficients of the aquifers.

\section{Examples of application}

\subsection{Application to calculating the natural recharge in the Duero basin (Spain)}

The Duero basin lies in northwest Spain and covers an area of almost $90000 \mathrm{~km}^{2}$. It receives an average rainfall of $621.3 \mathrm{~mm} \mathrm{yr}^{-1}$. It is a large sedimentary basin containing detrital and marly deposits, surrounded by predominantly carbonate mountain chains 25 (Fig. 2).

\section{HESSD}

$8,4753-4788,2011$

Calculating the average natural recharge in large areas

E. Sanz et al.

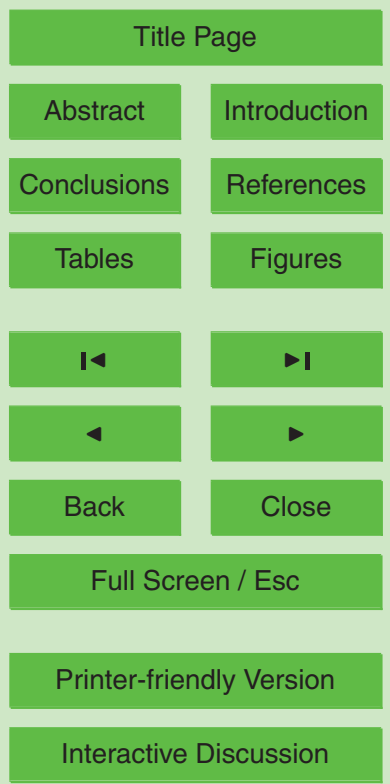


The basin was divided into 11 areas corresponding to, or delimited by, isohyets in $100 \mathrm{~m}$ increments, from $350 \mathrm{Im}^{-2}$ to $1450 \mathrm{Im}^{-2}$; with which the class marks of each area or interval a rounded with rainfall of $400 \mathrm{Im}^{-2}, 500 \mathrm{Im}^{-2}$ etc. Areas occupied by each of the lithological groups were calculated for each of these 11 areas.

These data were calculated using the 1:400 000 lithological map, marking the area of each lithological group and the average rainfall on each $5 \times 5 \mathrm{~km}$ grid square. $\Pi$ was then used from the table. The results for the entire Duero basin give the distribution shown in Table 7.

By this means, a total contribution of $3311.5 \mathrm{~h} \mathrm{~m}^{3} \mathrm{yr}^{-1}$ was obtained, which is very 10 similar to that obtained by Estrela et al. (1999) using a distributed mathematical model that applied to the whole of Spain and which gave an annual average natural recharge value of $3000 \mathrm{~h} \mathrm{~m}^{3} \mathrm{yr}^{-1}$ for the Duero basin.

\subsection{Application to calculating the natural recharge in several European countries}

15 As a means of illustration, the method has been applied to four western European countries: Spain, Portugal, Ireland and Italy, which have a sufficiently large area, varied lithology and varied rainfall. In addition, Spain is the most arid country in Europe and Ireland the wettest (Fig. 3). It is also assumed that the natural recharge has been evaluated sufficiently accurately. Table 10 summarises the area, average rainfall period 20 1901/1902-1995/1996 (CRU, 1998), and the average recharge calculated in previous work, along with the recharge calculated in the current study.

For Portugal, the recharge calculations were based on the separation of the base flow of certain rivers. Using the mean recharge values obtained for a number of catchments, regression lines were fitted with mean precipitation, which were then extrap25 olated to the remaining catchments (Lobo Ferreira et al., 1995; Oliveira et al., 1997; Carmona, 1999).

For Ireland, water balances were calculated from the real evapotranspiration using the Penman formula. Where possible, the recharge figure thus computed was 4764
HESSD

8, 4753-4788, 2011

Calculating the average natural recharge in large areas

E. Sanz et al.

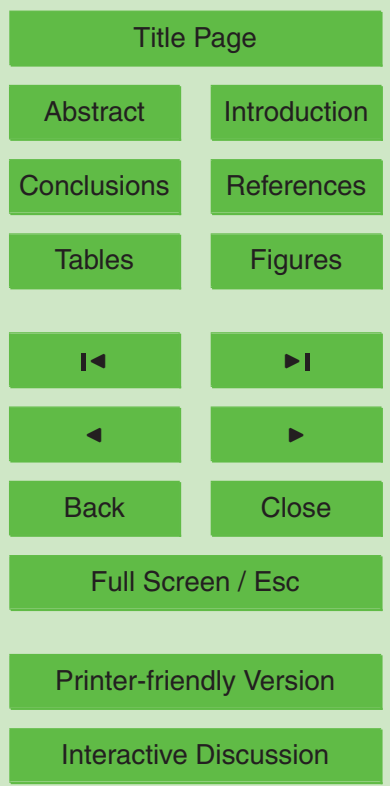

Interactive Discussion 
compared with a recharge estimate derived from base-flow separations from river hydrographs.

In Italy, catchment water balance studies are performed where many data exist, based on the evaluation of the basin output (base river flow, direct flow to the sea,

5 abstractions); analogy or mathematical models can also be used: infiltration values are then extrapolated to other formations.

For Spain, the 1:400000 map of Oriol Riba (1969) was used for lithological data, while for Portugal, Ireland and Italy, the CEC-Eurostat GISCO/1995 maps were used, which group the numerous differentiated lithologies into the six groups being consid10 ered. The lithological distribution can be seen in Table 8 and Fig. 4. To calculate the recharge, the coefficients $P_{i}$ from Table 6 and the average rainfall for each country were used.

The lack of precision resulting from the use of average rainfall will incur an error, though this is partially cancelled out by the fact that very extensive areas are being 15 co considered. The results obtained (Table 9), however, can be considered as quite acceptable, except, perhaps for Italy. In the case of Italy, the average recharge figure can probably be explained by two reasons: the first is that limestone outcrops in Italy are located mainly in areas receiving the highest rainfall, so that the higher than average rainfall should have been used in the calculations; secondly, Italy has a considerable area of volcanic rocks, whose recharge rate with respect to rainfall is unknown, although it is supposed that it is quite high.

\section{Conclusions}

This study presents a new technique for estimating the average natural recharge of large regions based on establishing indices or rates of recharge as a function of rainfall for six lithological groups of varying permeability.

The method was initially proven using a statistically large sample of springs, which was used to establish specific distribution functions of water supply of springs

\section{HESSD}

$8,4753-4788,2011$

\section{Calculating the average natural recharge in large areas}

E. Sanz et al.

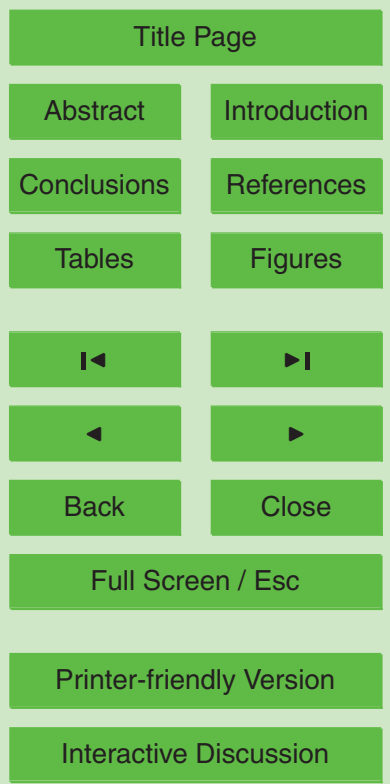


according to their discharge for different lithological groups in peninsular Spain (Sanz, 2001). This exercise confirms the validity of the general normal logarithmic function devised by Sanz (1996).

Subsequently, statistical inferences were made on the complete sample of springs 5 with discharges exceeding $10 \mathrm{Is}^{-1}$. The discharge and lithology of their recharge areas were known so that the springs could be grouped into four regions within Spain with varying rainfall. In this way, we showed that recharge is a fixed fraction of the average rainfall for each lithology and that it is independent of the temperature. Intermediate calculation steps were performed to validate the method, applying it to the Duero basin and to peninsular Spain.

The recharge rates, depending on rainfall, were obtained by adjusting provisional recharge rates obtained to the total estimated recharge under a natural regime in Spain complied by the L. B. A. (MIMAM, 2000) so that diffuse discharge were also considered.

The following recharge rates with respect to rainfall to Spain were established for 15 the six lithological groups considered.

\section{Lithology}

Alluvial sediments, sands, gravels

Conglomerates

The recharge rate of precipitation to groundwater to Spain (\%)

Sandstones

Limestones, Dolomites

Marls, limey marls, gypsum, silts, clays

Hard Rocks

The method proposed is already adjusted, and therefore needs no historical series. Calculation of the average recharge is based on knowledge of the surface distribution of a river basin, region or country, according to the six lithological groups. Once this distribution is known, the calculation can be applied to the average or annual recharge with prior knowledge only of the annual rain falling over each lithological group. These are applied to the recharge rates of Spain, which can be considered

$$
\begin{array}{r}
8.3 \\
5.6 \\
7.3 \\
34.3 \\
3.3 \\
1.3
\end{array}
$$

HESSD

8, 4753-4788, 2011

\section{Calculating the average natural recharge in large areas}

E. Sanz et al.

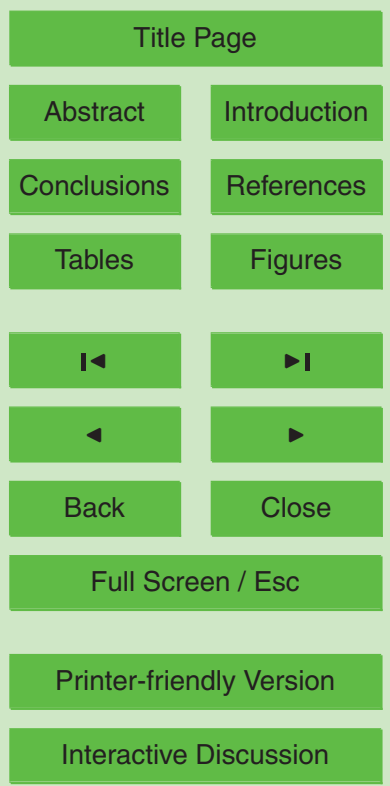


representative, or from other recharge rates that have been adjusted to each region. Thus, the method may be applied, except in very cold regions or other extreme cases (such as permafrost) to any region or country, since the rainfall and lithology data are easily acquired.

$5 \quad$ The method has been applied to the overall evaluation of the groundwater resources of the Duero basin in Spain and to four European countries, comparing the results with official statistics (Eurostat, 1998) obtained using different methods.

Our method allows the groundwater resources throughout the world to be evaluated approximately through the knowledge of readily available data: lithology and average 10 rainfall.

\section{References}

Carmona, A.: Water frameworks and water resources in Portugal, A contribution to the workshop overview on inland water in the Mediterranean EU countries, CEDEX, 15-16 July 1999, Madrid, Spain, 1999.

15 CEC - Eurostat/GISCO: European soil database, version 2.0, scale 1: 1000000 CECDGXI/CORINE and JRC-IRSA at ISPRA, 1995.

Cherkauer, D. S. and Ansari, S. A.: Estimating Groundwater Recharge from Topography, Hydrogeology and Land Cover, Ground Water, 43(1), 102-112, 2005.

CRU: Representing twentieth century space-time climate variability, in: II Development of 190196 monthly grids of terrestrial surface climate, edited by: New, M., Hulme, M., and Jones, P., Climate Research Unit School of Environmental Sciences, University of East Anglia, Norwich, NR, UK, 1998.

Dzhamalov, R. G. and Zektser, I. S.: World Map of Hydrogeological Conditions and Groundwater Flow, Scale 1:10000 000, compiled by: The Water Problems Institute of the Russian

25 Academy of Sciences under UNESCO supervision, Moscow, 1999.

EEA: European Environment Agency Data Service, last update 7/2001, 2001.

Estrela, T., Cabezas, F., and Estrada, F.: La evaluación de los recursos hídricos en el Libro Blanco del Agua en España, Revista de Ingeniería del Agua, 6(2), 125-138, 1999.
HESSD

$8,4753-4788,2011$

\section{Calculating the average natural recharge in large areas}

E. Sanz et al.

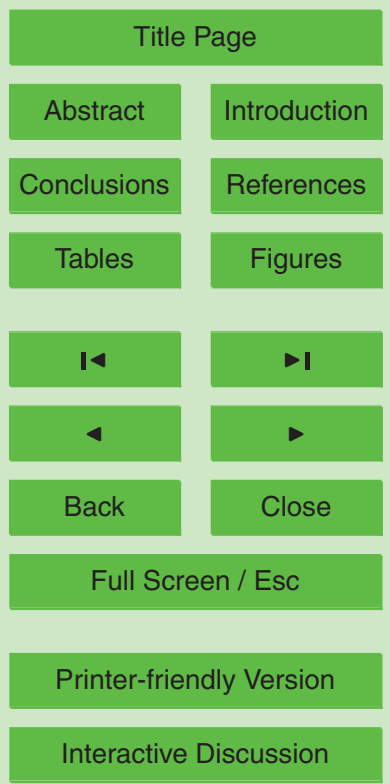


Eurostat: Water in Europe, Part 1. Renewable water resource, Office for official publications or the European communities, Luxembourg, 1998.

Horton, R. E.: Determination of infiltration capacity for large drainage basins, Trans. An. Geophys. Union, 18, 371, 1937.

5 IRSA: Water Research Institute, Italy: N. R. C. Long-Range study on water supply and demand in Europe, Level A: studies at country level - Italy, Rome, Italy, 1997.

Kennet-Smit, A., Cook, P. G., and Walker, G. R.: Factors affecting groundwater recharge following clearing in the south western Murray Basin. J. Hydrol., 154(1-4), 85-105, 1994.

Lerner, D. N.: Groundwater recharge, edited by: Saether, O. H. and de Caritat, P.,

10 A. A. Balkema, Rotterdam, The Netherlands, 109-150, 1997.

Lobo Ferreira, J. P., Oliveira, M., and Ciabatti, P.: Desenvolvimiento de un inventario das aguas subterrâneas de Portugal, LNEC, Dep. Hidráulica, I, 525 pp., 1995.

MIMAM - Ministerio del Medio Ambiente: Dirección General de Obras Hidráulicas y Calidad de las Aguas, Libro Blanco del Agua en España, Centro de Publicaciones de la Secretaría

15 General Técnica MIMAM, Madrid, Spain, 637 pp., 2000a.

MIMAM - Ministerio del Medio Ambiente: Las aguas continentales en los países mediterráneos de la Unión Europea, edited by: Estrela, T., Marcuello, C., and Dimas, M., CEDEX-Centro de Estudios y Experimentación de Obras Públicas, Madrid, Spain, 243 pp., 2000b.

MIMAM - Ministerio del Medio Ambiente: Las aguas continentales en la Unión Europea, edited by: Dimas, M., Estrela, T., Ordiérez, P., and Krinner, W., CEDEX-Centro de Estudios y Experimentación de Obras Públicas, Madrid, Spain, 387 pp., 2004.

Oliveira, M., Moinante, J., and Lobo Ferreira, J. P.: Determinaçao da recarga de águas subterrâneas a partir da análise de hidrogramas de escoamento, Seminário sobre Águas Subterrâneas, APRH - Assoc. Portg. Rec. Hid., Lisboa, Portugal, 1997.

Riba Anderieu, O.: Mapa litológico de España a escala 1:500 000, IGME, Instituto Nacional de Edafología y Servicio Geológico de Obras Públicas, Madrid, Spain, 1969.

Sanz, E.: Springs in Spain: Classification according to their flows and lithologies and their hydraulic contributions, Ground Water, 34(6), 1033-1041, 1996.

Sanz, E.: Distribution functions of spring discharge according to their lithologies and the influence of lower limit to flow in Spain, Ground Water, 36(2), 96-104, 2001.

Scanlon, B. R., Healy, R. W., and Cook, P.: Choosing appropriate techniques for quantifying groundwater recharge, Hydrogeol. J., 10, 18-39, 2002.

Simmers, I.: Estimation of natural groundwater recharge, Reidel, Boston, 550 pp., 1988.

HESSD

8, 4753-4788, 2011

\section{Calculating the average natural \\ recharge in large areas}

E. Sanz et al.

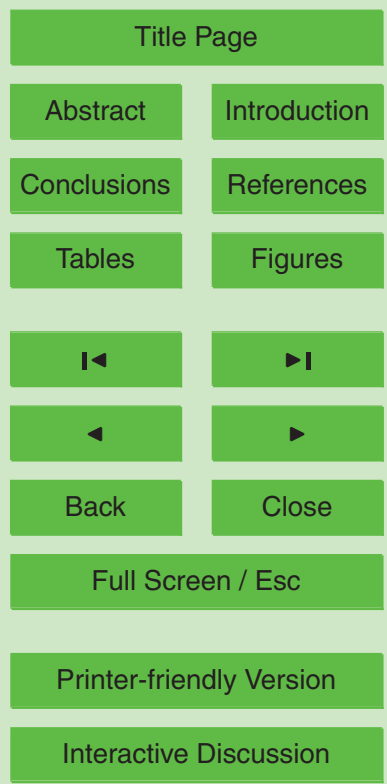


WHYMAP - Word-wide Hydrogeological Mapping and Assessment Programme, Groundwater Resources of the World Map, Scale 1:25000 000, BGR Hannover/UNESCO Paris, 2008.

WRI: World Resources 2000-2001, Water Resource Institute (WRI), http://wri.org, last access: 20 January, 2009.

\section{HESSD}

8, 4753-4788, 2011

\section{Calculating the} average natural recharge in large areas

E. Sanz et al.

Title Page

Abstract Introduction

Conclusions References

Tables Figures

14

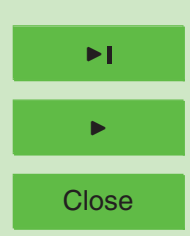

Back

Full Screen / Esc

Printer-friendly Version

Interactive Discussion 


\section{HESSD}

$8,4753-4788,2011$

Table 1. Hydraulic contribution distribution functions and annual hydraulic contribution.

\begin{tabular}{lrrlrr}
\hline Lithologic groups & Area $\left[\mathrm{km}^{2}\right]$ & $\begin{array}{r}a(x) \text { function } \\
\text { of hydraulic } \\
\text { contributions }\end{array}$ & $\begin{array}{l}\text { Literal } \\
\text { interpretation of } \\
\text { part }\end{array}$ & \multicolumn{2}{c}{$\begin{array}{l}\text { Annual hydraulic } \\
\text { contribution } \\
\left.\text { [h m}{ }^{3}\right]\end{array}$} \\
& & & $\mathrm{h} \mathrm{m}^{3}$ & $\%$ \\
\hline Alluvials, sands, gravels & 80104 & $252.0 \times^{-1.08}$ & $\int^{-1.08} x d x=11.0$ & 2772.0 & 16.0 \\
Conglomerates & 31141 & $55.4 \times^{-0.89}$ & $\int^{-0.89} x d x=12.5$ & 688.8 & 4.0 \\
Sandstones & 19213 & $64.5 \times^{-1.02}$ & $\int^{-1.02} x d x=9.2$ & 593.4 & 3.4 \\
Limestones and dolomites & 74582 & $146.3 \times^{-1.27}$ & $\int^{-1.27} x d x=11.9$ & 1741.0 & 10.1 \\
Marls, silts, clays & 123963 & $96.8 \times^{-1.44}$ & $\int^{-1.44} x d x=10.0$ & 963.2 & 5.5 \\
All groups & 497477 & $1069 \times^{-0.91}$ & $\int^{-0.91} x d x=16.2$ & 17312.1 & 100.0 \\
\hline
\end{tabular}

(1) $a(x)$ in $\mathrm{hm}^{3}$ and $x$ in $\mathrm{Is}^{-1}$,

${ }^{(2)}$ Integrals have as lower limit $0.01 / \mathrm{s}^{-1}$ and as higher the maximum of each group.

\section{Calculating the average natural} recharge in large areas

E. Sanz et al.

Title Page

Abstract

Introduction

Conclusions

References

Tables

Figures

14

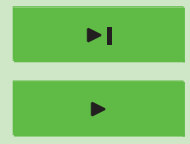

Back

Close

Full Screen / Esc

Printer-friendly Version

Interactive Discussion 
Table 2. Number of springs according to flow, contributions and lithological areas.

\begin{tabular}{|c|c|c|c|c|c|c|c|c|c|c|c|}
\hline \multirow{3}{*}{$\begin{array}{l}\text { Flow } \\
\text { intervals } \\
\left(\mathrm{Is}^{-1}\right)\end{array}$} & \multirow{3}{*}{$\begin{array}{l}\text { Class } \\
\text { Marks }\end{array}$} & \multicolumn{5}{|c|}{ Number of springs } & \multicolumn{5}{|c|}{ Hydraulic Contributions in $\mathrm{h} \mathrm{m}^{3} \mathrm{yr}^{-1}$} \\
\hline & & \multicolumn{5}{|c|}{ Geographic zones } & \multicolumn{5}{|c|}{ Geographic zones } \\
\hline & & 1 & 2 & 3 & 4 & Total & 1 & 2 & 3 & 4 & Total \\
\hline \multicolumn{12}{|c|}{ Lithology 1. Alluvials, sands and gravels } \\
\hline $11-50$ & 30 & 5 & 17 & 39 & 16 & 77 & $4.7^{*}$ & 16.1 & 36.9 & 15.1 & 72.8 \\
\hline $51-100$ & 75 & 1 & 3 & 8 & 7 & 19 & 2.4 & 7.1 & 18.9 & 16.5 & 44.9 \\
\hline $101-200$ & 150 & - & - & 4 & 2 & 6 & - & - & 18.9 & 9.5 & 28.4 \\
\hline $201-500$ & 350 & - & - & 1 & - & 1 & - & - & 11.0 & - & 11 \\
\hline $501-1000$ & 750 & - & - & 1 & - & 1 & - & - & 23.7 & - & 23.7 \\
\hline $1001-1500$ & 1250 & - & - & - & - & - & - & - & - & - & - \\
\hline 1501-2000 & 1750 & - & 1 & - & - & 1 & - & 55.2 & - & - & 55.2 \\
\hline 2001 and more & 2000 & - & - & - & - & - & - & - & - & - & - \\
\hline All & & 6 & 21 & 53 & 25 & 105 & 7.1 & 78.4 & 109.4 & 41.1 & 236 \\
\hline \multicolumn{7}{|c|}{ Lithological area $\left(\mathrm{km}^{2}\right)$} & 100 & 2579 & 3666 & 1760 & 8105 \\
\hline \multicolumn{12}{|c|}{ Lithology 2. Conglomerates } \\
\hline $11-50$ & 30 & 1 & 8 & 10 & 8 & 27 & 1 & 7.5 & 9.5 & 7.6 & 25.6 \\
\hline $51-100$ & 75 & - & 4 & 2 & 2 & 8 & - & 9.5 & 4.7 & 4.7 & 18.9 \\
\hline $101-200$ & 150 & 1 & 2 & 2 & 1 & 6 & 4.7 & 9.5 & 9.5 & 4.7 & 28.4 \\
\hline $201-500$ & 350 & 1 & - & 1 & - & 2 & 11 & - & 11.1 & - & 22.1 \\
\hline All & & 3 & 14 & 15 & 11 & 43 & 16.7 & 26.5 & 34.8 & 17 & 95 \\
\hline \multicolumn{7}{|c|}{ Lithological area $\left(\mathrm{km}^{2}\right)$} & 330 & 1178 & 1904 & 1110 & 4522 \\
\hline \multicolumn{12}{|c|}{ Lithology 3. Sandstones } \\
\hline $11-50$ & 30 & 6 & 1 & 11 & 3 & 21 & 5.9 & 1 & 10.8 & 2.9 & 20.6 \\
\hline $51-100$ & 75 & - & 1 & - & 1 & 2 & - & 2.4 & - & 2.4 & 4.8 \\
\hline \multirow{2}{*}{\multicolumn{7}{|c|}{$\begin{array}{l}\text { All } \begin{array}{ccc}6 & 2 & 11 \\
\text { Lithological area }\left(\mathrm{km}^{2}\right)\end{array}\end{array}$}} & 5.9 & 3.4 & 10.8 & 5.3 & 25.4 \\
\hline & & & & & & & 87 & 125 & 427 & 267 & 906 \\
\hline
\end{tabular}

HESSD

$8,4753-4788,2011$

Calculating the average natural recharge in large areas

E. Sanz et al.

Title Page

Abstract

Introduction

Conclusions

References

Tables

Figures
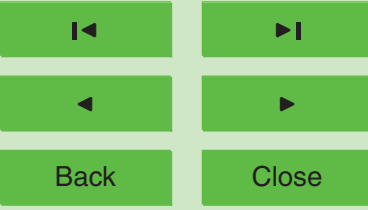

Back

Close

\section{Full Screen / Esc}

Printer-friendly Version

Interactive Discussion 


\section{HESSD}

8, 4753-4788, 2011

Table 2. Continued.

\begin{tabular}{|c|c|c|c|c|c|c|c|c|c|c|c|}
\hline \multirow{3}{*}{$\begin{array}{l}\text { Flow } \\
\text { intervals } \\
\left(\mathrm{Is}^{-1}\right)\end{array}$} & \multirow{3}{*}{$\begin{array}{l}\text { Class } \\
\text { Marks }\end{array}$} & \multicolumn{5}{|c|}{ Number of springs } & \multicolumn{5}{|c|}{ Hydraulic Contributions in $\mathrm{h} \mathrm{m}^{3} \mathrm{yr}^{-1}$} \\
\hline & & \multicolumn{5}{|c|}{ Geographic zones } & \multicolumn{5}{|c|}{ Geographic zones } \\
\hline & & 1 & 2 & 3 & 4 & Total & 1 & 2 & 3 & 4 & Total \\
\hline \multicolumn{12}{|c|}{ Lithology 4. Limestones and Dolomites } \\
\hline $11-50$ & 30 & 62 & 181 & 121 & 92 & 456 & 58.7 & 171.2 & 114.5 & 87.0 & 431.4 \\
\hline $51-1$ & 75 & 5 & 28 & 29 & 15 & & 11.8 & 66.2 & 68.6 & 35.5 & 182.1 \\
\hline $101-$ & 150 & 6 & 12 & 17 & 12 & & 28.4 & & & 56.8 & 222.4 \\
\hline $201-500$ & 350 & 2 & 12 & 12 & 11 & 37 & 22.1 & 132.5 & 132.5 & 121.4 & 408.5 \\
\hline $501-$ & & 2 & 14 & 5 & 9 & & 47.3 & 331 & 118.3 & 212.9 & 709.6 \\
\hline $1001-1$ & 1250 & 2 & 2 & - & 5 & 9 & 78.8 & 78.8 & - & 193.1 & 354.7 \\
\hline 1501-2000 & 1750 & - & 1 & 1 & 2 & 4 & - & - & 55.2 & 110.4 & 220.8 \\
\hline 2001 and more & 2000 & 1 & 1 & 1 & 1 & 4 & 63.1 & 63.1 & 63.1 & 63.1 & 252.3 \\
\hline All & & 80 & 251 & 186 & 147 & 664 & 310.2 & 954.8 & 632.6 & 884.2 & 2781.8 \\
\hline \multicolumn{7}{|c|}{ Lithological area $\left(\mathrm{km}^{2}\right)$} & 1189 & 6988 & 5126 & 9146 & 22449 \\
\hline \multicolumn{12}{|c|}{ Lithology 5. Marls, limely marls, silts and clays } \\
\hline $11-50$ & 30 & 6 & 7 & 16 & 4 & 33 & 5.7 & 6.6 & 15.1 & 3.8 & 31.2 \\
\hline & 75 & 1 & - & 2 & - & 3 & 2.4 & - & 4.7 & - & 7.1 \\
\hline $101-200$ & 150 & - & 1 & 3 & - & 4 & - & 4.7 & 142.0 & - & 18.8 \\
\hline All & & 7 & 8 & 21 & 4 & 40 & 8.1 & 11.3 & 34.0 & 3.8 & 57.2 \\
\hline \multicolumn{7}{|c|}{ Lithological area $\left(\mathrm{km}^{2}\right)$} & 260 & 831 & 3113 & 373 & 4577 \\
\hline
\end{tabular}

Calculating the average natural recharge in large areas

E. Sanz et al.

Title Page

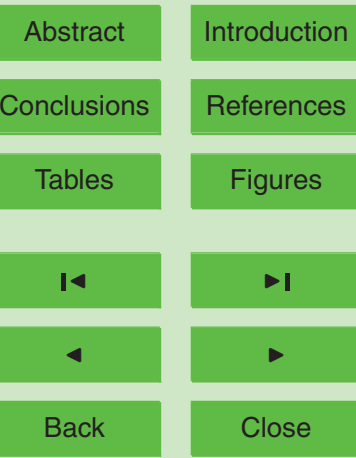

Full Screen / Esc

${ }^{*} 30.5(3600 \times 24 \times 365) / 10^{9}=30.5 \times 0.031536=4.7304$

Printer-friendly Version

Interactive Discussion 
Table 3. Percentage of precipitation recharged in each lithological group.

\begin{tabular}{|c|c|c|c|c|c|}
\hline $\begin{array}{l}\text { Geographics } \\
\text { zones }\end{array}$ & $\begin{array}{r}\text { Area } S \\
\left(\mathrm{~km}^{2}\right)\end{array}$ & $\begin{array}{r}\text { Hydraulic } \\
\text { Contribution } A \\
\left(\mathrm{~km}^{2}\right)\end{array}$ & $\begin{array}{l}A / S \\
\left(\mathrm{Im}^{-2}\right)\end{array}$ & $\begin{array}{l}\text { Precipitation } P \\
\left(\mathrm{Im}^{-2}\right)\end{array}$ & $\begin{array}{r}\% \\
\text { Precipitation } \\
\text { infiltrated } \\
P_{i}\end{array}$ \\
\hline \multicolumn{6}{|c|}{ Lithology 1. Alluvials, sands y gravels } \\
\hline North & 100 & 7.1 & 71.1 & 1428 & 5.0 \\
\hline Center & 2579 & 78.4 & 30.4 & 660 & 4.6 \\
\hline South & 3606 & 109.4 & 29.8 & 563 & 5.3 \\
\hline Levante & 1760 & 41.1 & 23.4 & 467 & 5.0 \\
\hline All & 8105 & 236 & 29.1 & $583^{*}$ & 5.0 \\
\hline \multicolumn{6}{|c|}{ Lithology 2. Conglomerates } \\
\hline North & 330 & 16.7 & 50.6 & 1428 & 3.5 \\
\hline Center & 1178 & 26.5 & 22.5 & 660 & 3.4 \\
\hline South & 1904 & 34.8 & 18.3 & 563 & 3.2 \\
\hline Levante & 1110 & 17 & 15.3 & 467 & 3.3 \\
\hline All & 4522 & 95 & 21 & $627^{*}$ & 3.4 \\
\hline \multicolumn{6}{|c|}{ Lithology 3. Sandstones } \\
\hline North & 87 & 5.9 & 67.8 & 1428 & 4.7 \\
\hline Center & 125 & 3.4 & 27.2 & 660 & 4.1 \\
\hline South & 427 & 10.8 & 25.3 & 563 & 4.5 \\
\hline Levante & 267 & 5.3 & 19.9 & 467 & 4.3 \\
\hline All & 906 & 25.4 & 28 & $631^{*}$ & 4.4 \\
\hline
\end{tabular}

HESSD

8, 4753-4788, 2011

Calculating the average natural recharge in large areas

E. Sanz et al.

\section{Title Page}

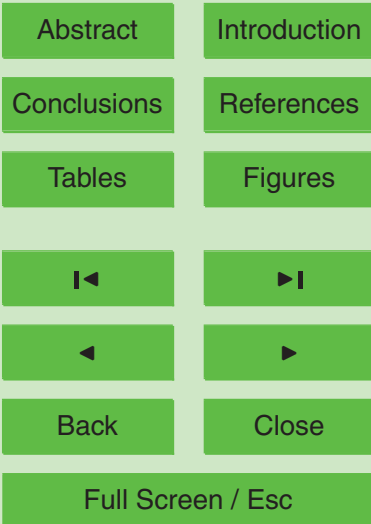

Printer-friendly Version

Interactive Discussion 


\section{HESSD}

8, 4753-4788, 2011

Table 3. Continued.

\begin{tabular}{|c|c|c|c|c|c|}
\hline $\begin{array}{l}\text { Geographics } \\
\text { zones }\end{array}$ & $\begin{array}{r}\text { Area } S \\
\left(\mathrm{~km}^{2}\right)\end{array}$ & $\begin{array}{r}\text { Hydraulic } \\
\text { Contribution } A \\
\left(\mathrm{~km}^{2}\right)\end{array}$ & $\begin{array}{r}A / S \\
\left(\mathrm{Im}^{-2}\right)\end{array}$ & $\begin{array}{l}\text { Precipitation } P \\
\left(\mathrm{Im}^{-2}\right)\end{array}$ & $\begin{array}{r}\% \\
\text { Precipitation } \\
\text { infiltrated } \\
P_{i}\end{array}$ \\
\hline \multicolumn{6}{|c|}{ Lithology 4. Limestones and Dolomites } \\
\hline North & 1189 & 310.2 & 260.9 & 1428 & 18.3 \\
\hline Center & 6938 & 954.8 & 136.6 & 660 & 20.7 \\
\hline South & 5126 & 632.6 & 123.4 & 563 & 21.9 \\
\hline Levante & 9146 & 884.2 & 96.7 & 467 & 20.7 \\
\hline All & 22449 & 2781.8 & 123.9 & $600^{*}$ & 20.7 \\
\hline \multicolumn{6}{|c|}{ Lithology 5. Marls, limely marls, silts and clays } \\
\hline North & 260 & 8.1 & 31.2 & 1428 & 2.2 \\
\hline Center & 831 & 11.3 & 13.6 & 660 & 2.1 \\
\hline South & 3113 & 34 & 10.9 & 563 & 1.9 \\
\hline Levante & 373 & 3.8 & 10.2 & 467 & 2.2 \\
\hline All & 4577 & 57.2 & 12.5 & $622^{*}$ & 2 \\
\hline
\end{tabular}

${ }^{*}$ Weight mean values by surface.

\section{Calculating the} average natural recharge in large areas

E. Sanz et al.

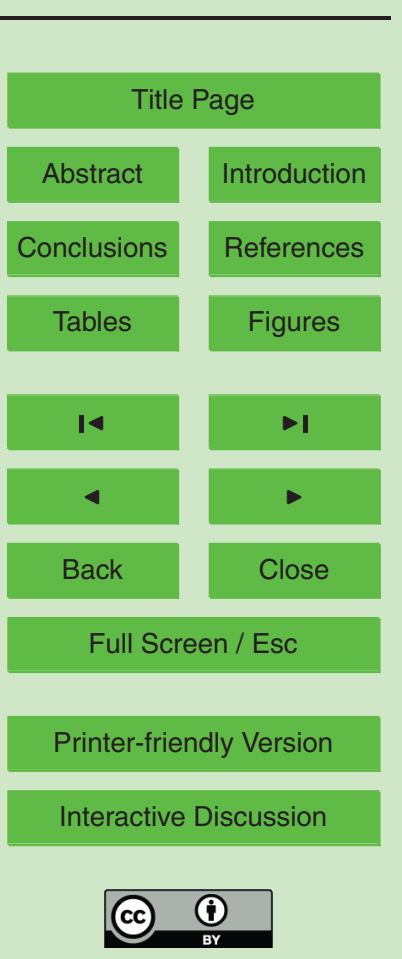




\section{HESSD}

8, 4753-4788, 2011

Table 4. Percentage of precipitation destined to recharge $\left(P_{i}\right)$.

\begin{tabular}{llllrr}
\hline $\begin{array}{l}\text { Geographics } \\
\text { zones }\end{array}$ & $\begin{array}{l}\text { 1. Alluvials, } \\
\text { sands and } \\
\text { gravels }\end{array}$ & 2. Conglomerates & 3. Sandstones & $\begin{array}{r}\text { 4. Limestones } \\
\text { and } \\
\text { Dolomites }\end{array}$ & $\begin{array}{r}\text { 5. Marls, } \\
\text { Silts } \\
\text { and } \\
\text { Clays }\end{array}$ \\
\hline North & 5.0 & 3.5 & 4.7 & 18.3 & 2.2 \\
Center & 4.6 & 3.4 & 4.1 & 20.7 & 2.1 \\
South & 5.3 & 3.2 & 4.5 & 21.9 & 1.9 \\
Levante & 5.0 & 3.3 & 4.3 & 20.7 & 2.2 \\
Mean $(\bar{X})$ & 5.0 & 3.4 & 4.4 & 20.7 & 2.0 \\
$\sigma^{2}$ & 0.17 & 0.67 & 0.05 & 5.4 & 0.1 \\
$\sigma$ & 0.4 & 0.8 & 0.2 & 2.3 & 0.3 \\
$\sigma / \bar{X}(\%)$ & 8.2 & 23.5 & 5.1 & 11.2 & 15.1 \\
\hline
\end{tabular}

\section{Calculating the} average natural recharge in large areas

E. Sanz et al.

Title Page

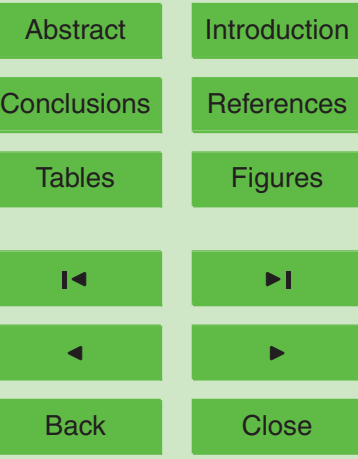

Full Screen / Esc

Printer-friendly Version

Interactive Discussion 


\section{HESSD}

8, 4753-4788, 2011

Table 5. Estimate of recharge in peninsular Spain.

\begin{tabular}{lrcrrr}
\hline Lithological Groups & $\begin{array}{r}\text { Area } S_{i} \\
\left(10^{3} \mathrm{~km}^{2}\right)\end{array}$ & $\begin{array}{r}\text { Precipitation } \\
\left(\mathrm{I} \mathrm{m}^{-2}\right)\end{array}$ & $\begin{array}{r}P_{i} \\
(\%)\end{array}$ & $\begin{array}{r}\text { Hydraulic } \\
\text { Contribution } \\
\left(\mathrm{h} \mathrm{m}^{3}\right)\end{array}$ & $\begin{array}{r}\text { Showed } \\
\text { in the } \\
\text { Table 1 }\end{array}$ \\
\hline Alluvials, sands and gravels & 80.104 & 687 & 5.0 & 2752 & 2752 \\
Conglomerates & 31.141 & 687 & 3.4 & 727 & 689 \\
Sandstones & 19.213 & 687 & 4.4 & 581 & 593 \\
Limestones and Dolomites & 74.582 & 687 & 20.7 & 10606 & 10554 \\
Marls, silts, clays & 123.464 & 687 & 2.0 & 1696 & 1741 \\
Others & 168.973 & 687 & 0.8 & 964 & 963 \\
All & 497.477 & & & 17326 & 17312 \\
\hline
\end{tabular}

Calculating the average natural recharge in large areas

E. Sanz et al.

Title Page

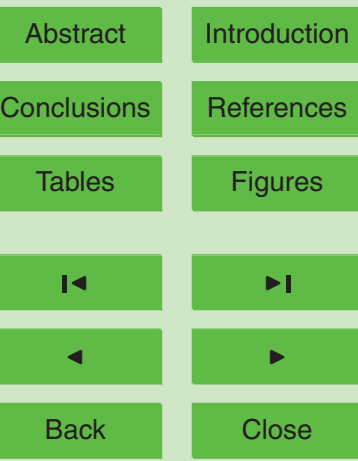

Full Screen / Esc

Printer-friendly Version

Interactive Discussion 


\section{HESSD}

8, 4753-4788, 2011

Table 6. Recharge rates with respect to precipitation, according to lithological group.

\begin{tabular}{lrrr}
\hline Lithologies & $P_{i}(\%)$ & \multicolumn{2}{c}{ Recharge of } \\
& & $\begin{array}{r}\text { peninsular } \\
\mathrm{km}^{2}\end{array}$ & $\begin{array}{r}\text { Spain } \\
\%\end{array}$ \\
& & & 15.9 \\
Alluvials, sands, gravels & 8.29 & 4562 & 15.9 \\
Conglomerates & 5.63 & 1204 & 4.2 \\
Sandstones & 7.29 & 962 & 3.4 \\
Limestones, Dolomites & 34.31 & 17580 & 61.4 \\
Marls, silts, clays & 3.32 & 2816 & 9.8 \\
Others & 1.32 & 1532 & 5.3 \\
\hline \multicolumn{1}{c}{ Total } & & 28656 & 100 \\
\hline \multicolumn{2}{c}{ Tot }
\end{tabular}

\section{Calculating the} average natural recharge in large areas

E. Sanz et al.

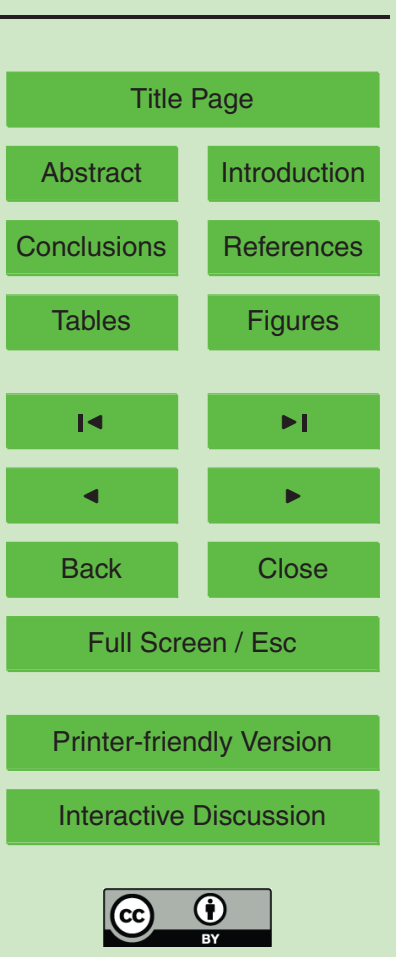




\section{HESSD}

$8,4753-4788,2011$

Table 7. Calculation of hydraulic contributions to the Duero catchment (Spain).

\begin{tabular}{|c|c|c|c|c|c|c|c|c|}
\hline \multicolumn{2}{|c|}{ Precipitation $\left(\mathrm{Im}^{-2}\right)$} & \multicolumn{7}{|c|}{ Lithological Areas $\left(\mathrm{km}^{2}\right)$} \\
\hline Intervals & Class marks & Alluvials & Conglomerates & Sandstones & Limestones & Marls & Others & Total \\
\hline $350-449$ & 400 & 6311 & 1126 & 80 & 1122 & 7327 & 852 & 16818 \\
\hline $450-549$ & 500 & 5296 & 1803 & 193 & 3580 & 7184 & 3500 & 21556 \\
\hline $550-649$ & 600 & 2403 & 2209 & 237 & 1387 & 2992 & 3169 & 12397 \\
\hline $650-749$ & 700 & 1020 & 1431 & 223 & 893 & 1072 & 3336 & 7975 \\
\hline 750-849 & 800 & 793 & 523 & 190 & 164 & 269 & 6352 & 8291 \\
\hline 850-949 & 900 & 1035 & 1047 & 165 & 329 & 1094 & 1857 & 5527 \\
\hline 950-1049 & 1000 & 141 & 262 & 152 & 180 & 513 & 2858 & 4106 \\
\hline 1050-1149 & 1100 & - & - & 19 & 106 & - & 980 & 1105 \\
\hline $1150-1249$ & 1200 & - & - & - & - & - & - & - \\
\hline $1250-1349$ & 1300 & - & - & 16 & 56 & - & 481 & 553 \\
\hline $1350-1449$ & 1400 & 10 & - & - & 88 & - & 534 & 632 \\
\hline All & & 17009 & 8401 & 1275 & 7905 & 20451 & 23919 & 78960 \\
\hline$\%$ & & 21.5 & 10.6 & 1.6 & 10 & 25.9 & 30.4 & 100 \\
\hline Spain \% & & 16.1 & 6.3 & 3.9 & 15 & 24.8 & 33.9 & 100 \\
\hline Precipitation & & 532.02 & 631.08 & 722.35 & 583.93 & 527.17 & 768.81 & 621.3 \\
\hline $\begin{array}{l}\text { Hydraulic } \\
\text { contribution }\end{array}$ & $\left.\mathrm{m}^{3}\right)$ & 751 & 296.9 & 67.2 & 1583.2 & 355.8 & 2574 & 3311.5 \\
\hline
\end{tabular}

\section{Calculating the average natural recharge in large areas}

E. Sanz et al.

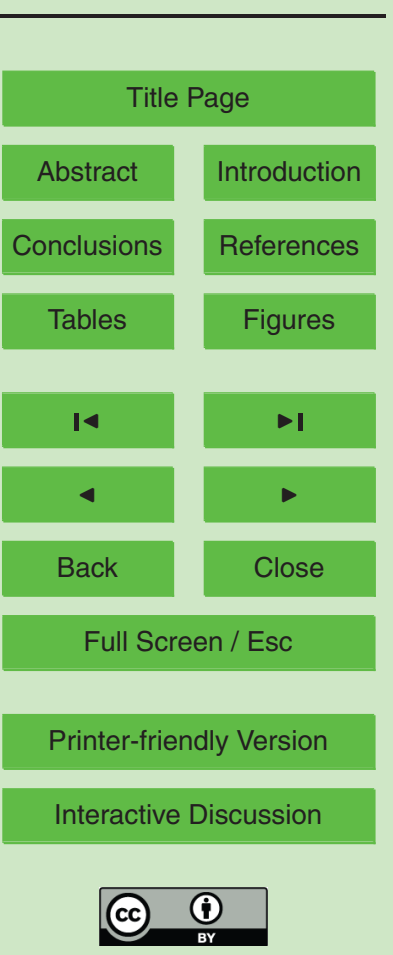


Table 8. Calculation of the average recharge for springs, for four European countries (Spain, Portugal, Ireland and Italy) and the classification of lithologies from CEC-Eurostat GISCO (1995) into six groups.

\begin{tabular}{|c|c|c|c|c|c|}
\hline Country & Lithology & $\begin{array}{r}\text { Area } \\
\left(\mathrm{km}^{2}\right)\end{array}$ & $P_{m}\left(\mathrm{Im}^{2}\right)$ & $P_{i}$ & $\begin{array}{l}\text { Recharge for spring } \\
\qquad\left(\mathrm{h} \mathrm{m}^{3} \mathrm{yr}^{-1}\right)\end{array}$ \\
\hline Peninsular & Alluvials & 80104 & 687 & 0.05 & 2751.6 \\
\hline \multirow[t]{6}{*}{ Spain } & Conglomerates & 31141 & 687 & 0.034 & 727.4 \\
\hline & Sandstones & 19213 & 687 & 0.044 & 580.8 \\
\hline & Limestones & 74582 & 687 & 0.21 & 10760.0 \\
\hline & Marls & 123464 & 687 & 0.02 & 1696.4 \\
\hline & Others & 168973 & 687 & 0.008 & 928.6 \\
\hline & Total & 497477 & 687 & - & 17444.8 \\
\hline \multirow[t]{7}{*}{ Portugal } & Alluvials & 12485 & 882 & 0.05 & 550.6 \\
\hline & Conglomerates & 0 & 882 & 0.034 & 0 \\
\hline & Sandstones & 13516 & 882 & 0.044 & 524.5 \\
\hline & Limestones & 5500 & 882 & 0.21 & 1018.7 \\
\hline & Marls & 1678 & 882 & 0.02 & 29.6 \\
\hline & Others & 56720 & 882 & 0.008 & 400.2 \\
\hline & Total & 89898 & 882 & - & 2523.6 \\
\hline \multirow[t]{7}{*}{ Ireland } & Alluvials & 3384 & 1150 & 0.05 & 194.6 \\
\hline & Conglomerates & 0 & 1150 & 0.034 & 0 \\
\hline & Sandstones & 11758 & 1150 & 0.044 & 595.0 \\
\hline & Limestones & 24446 & 1150 & 0.21 & 5903.7 \\
\hline & Marls & 0 & 1150 & 0.02 & 0 \\
\hline & Others & 29989 & 1150 & 0.008 & 275.9 \\
\hline & Total & 69577 & 1150 & - & 6969.2 \\
\hline \multirow[t]{8}{*}{ Italy } & Alluvials & 80722 & 982 & 0.05 & 3963.4 \\
\hline & Conglomerates & 0 & 982 & 0.034 & 0 \\
\hline & Sandstones & 31812 & 982 & 0.044 & 1374.5 \\
\hline & Limestones & 71911 & 982 & 0.21 & 14829.5 \\
\hline & Marls & 59212 & 982 & 0.02 & 1162.9 \\
\hline & Others & 41204 & 982 & 0.008 & 323.7 \\
\hline & volcanics & 17694 & 982 & 0.12 & 2085 \\
\hline & Total & 302557 & 982 & - & 23739 \\
\hline
\end{tabular}

\section{HESSD}

$8,4753-4788,2011$

Calculating the average natural recharge in large areas

E. Sanz et al.

Title Page

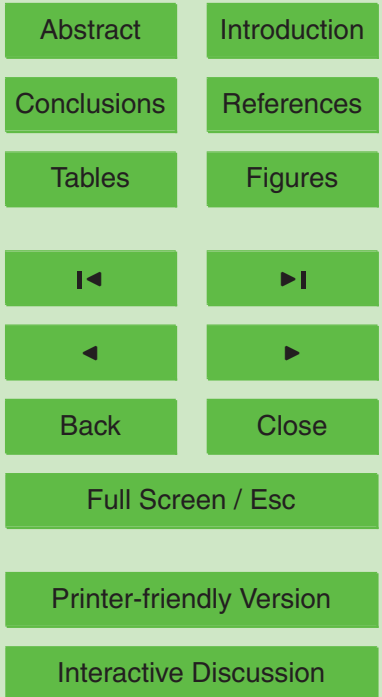




\section{HESSD}

8, 4753-4788, 2011

Table 8. Continued.

\begin{tabular}{lrrl}
\hline Country & $\begin{array}{r}\text { Recharge for springs } \\
\text { estimated in this work } \\
\left(\mathrm{h} \mathrm{m}^{3} \mathrm{yr}^{-1}\right)\end{array}$ & $\begin{array}{r}\text { Total } \\
\left.\mathrm{Recharge}^{3} \mathrm{~h} \mathrm{~m}^{3} \mathrm{yr}^{-1}\right)\end{array}$ & $\begin{array}{l}\text { Recharge for } \\
\text { spring/Total } \\
\text { Recharge }\end{array}$ \\
\hline Peninsular Spain & 17444.8 & $28908^{1}$ & 1.66 \\
Portugal & 2523.6 & $4000^{2}$ & 1.58 \\
Ireland & 6969.2 & $10800^{3}$ & 1.54 \\
Italy & 23739 & $43000^{4}$ & 1.81 \\
Duero Basin & 2005.2 & $3000^{1}$ & 1.5 \\
\hline
\end{tabular}

\section{Calculating the average natural recharge in large areas \\ E. Sanz et al.}

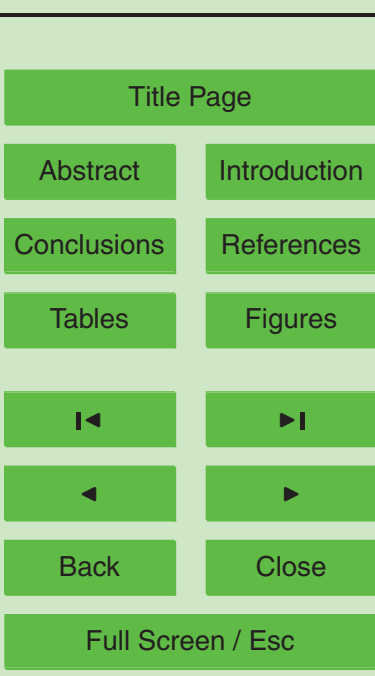

Printer-friendly Version

${ }^{1}$ MIMAM (2002); Estrela et al. (1999).

${ }^{2}$ MIMAM (2002b); Carmona (1999).

${ }^{3}$ MIMAM (2004); EEA (2001); WRI (2001).

${ }^{4}$ MIMAM (2002b); IRSA (1997). 


\section{HESSD}

Table 8. Continued.

$8,4753-4788,2011$

\begin{tabular}{lll}
\hline No & Lithological Groups & Lithology of Eurostat-GISCO (Code, description) \\
\hline 1 & Alluvials, sands and & 100, Undifferenciate alluvial deposits (or glacial deposits); \\
& gravels & 110, River alluvium; 111, Old fluviatile deposit (tertiary); \\
& & 112, Terraces; 130, Glaciofluvial deposits; 131, Till; 140, \\
& & Glaciofluvial drift; 400, Sandy materials; 410, Old sandy \\
& sedimentary deposits; 411, secondary sands; 412, Tertiary \\
& sands; 420, Alluvial or glaciofluvial sands; 421, Glacial \\
& sands; 422, Sandy gravely materials; 430, Eolian sands; 431, \\
& Locally coversand; 440, Coastal sands (Dune sands); 441, \\
& Shelly coastal sands; 442, Non calcareous coastal sands; 600, \\
& detrital formations \\
\hline 2 & Conglomerates & 620, Breche + Poudingues \\
\hline 3 & Sandstones & 450, Sandstone; 451, Calcareous sandstone (Macigno); 452, \\
& & Ferrugineous sandstone (old red sandstone); 453, Clayey \\
& sandstone; 454, Soft quartz sandstone; 455, Hard quartz \\
& sandstone; 610, Arkose; 630, Flysch + Molasse
\end{tabular}

$4 \quad$ Limestones and

200, calcareous rocks; 210, Limestone; 211, Primary

Dolomites

limestone (carboniferous); 212, Secondary limestone; 213,

Tertiary limestone; 214, ferrugineous limestone; 215, Hard

limestone; 216, Soft limestone; 220, secondary chalk;

250, Dolomite

\section{Calculating the average natural \\ recharge in large areas}

E. Sanz et al.

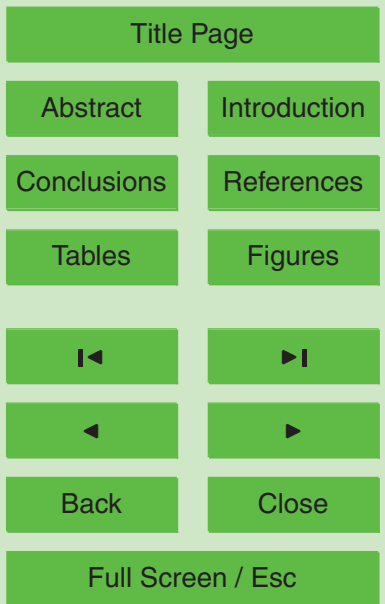

Printer-friendly Version

Interactive Discussion 


\section{HESSD}

Table 8. Continued.

\begin{tabular}{|c|c|c|}
\hline No & Lithological Groups & Lithology of Eurostat-GISCO (Code, description) \\
\hline 5 & Marls, Silts and Clays & $\begin{array}{l}\text { 120, Estuarine/Marine alluvium; } 230 \text {, Marl; 231, secondary } \\
\text { marl; 232, Tertiary marl; 233, Gypseous Marl; } 300 \text {, Clayey } \\
\text { materials; 310, Old clayey sedimentary deposits; } 311 \text {, } \\
\text { Primary clay and sandstone; } 312 \text {, secondary clay; } 313 \text {, } \\
\text { Tertiary clay; 320, Alluvial or glaciofluvial clay; 321, } \\
\text { Tertiary alluvial clay; 322, Glacial clay (tertiary and } \\
\text { quaternary); 323, Gravely clay; 324, Boulder clay; 330, } \\
\text { Residual clay from calcareous rocks; 331, flint clay (argile a } \\
\text { silex); 332, Siderolith formations; 340, Claystone mudstone; } \\
\text { 500, Loamy materials; 510, Residual loam; 511, Old loam } \\
\text { (Touyas); 512, Stony loam; 513, Clay loam; 520, Eoliam } \\
\text { loam; 521, Loess; 522, Locally loess; 523, Sandy loess; } \\
\text { 530, Siltstone; } 640, \text { Ranas }\end{array}$ \\
\hline 6 & Others & $\begin{array}{l}\text { 456, Quartzite; 700, Crystalline rocks; 710, Acid crystalline } \\
\text { rocks (+ migmatites); 711, Granite; 712, Diorite, } \\
\text { Quartzodiorite; 720, Nod acid crystalline rocks } \\
\text { (+ migmatites); 721, Syenite; 722, Gabbro; 730, Crystalline } \\
\text { metamorphic rocks; 731, Gneiss; 740, Schists; 741, } \\
\text { Micaschists; 742, Slates; 743, Shales; 744, Calcschists; 745, } \\
\text { Green schists; 750, Other metamorphic rocks; } 800, \text { Volcanic rocks; } \\
810 \text {, Acid volcanic rocks; } 820 \text {, Basic volcanic rocks; } \\
821 \text {, Phonolites; } 822, \text { Basalt; } 900 \text {, Other rocks }\end{array}$ \\
\hline
\end{tabular}

8, 4753-4788, 2011

\section{Calculating the average natural recharge in large areas}

E. Sanz et al.

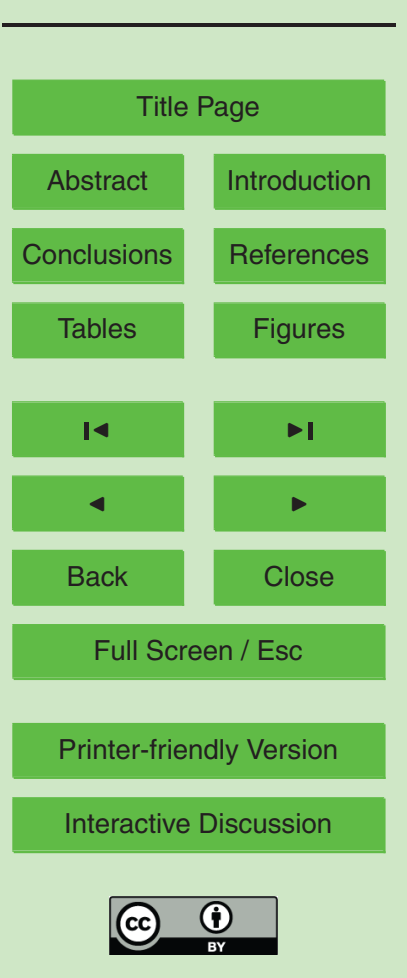


Table 9. Calculation of mean recharge in four countries in Europe (Spain, Portugal, Ireland and Italy).

\begin{tabular}{|c|c|c|c|c|c|}
\hline Country & Lithology & Area $\left(\mathrm{km}^{2}\right)$ & $P_{m}\left(\mathrm{Im}^{-2}\right)$ & $P_{i}$ & $\begin{array}{l}\text { Recharge } \\
\left(\mathrm{h} \mathrm{m}^{3} \mathrm{yr}^{-1}\right)\end{array}$ \\
\hline Peninsular & Alluvials & 80104 & 687 & 0.083 & 4567.6 \\
\hline \multirow[t]{6}{*}{ Spain } & Conglomerates & 31141 & 687 & 0.056 & 1198.1 \\
\hline & Sandstones & 19213 & 687 & 0.073 & 963.6 \\
\hline & Limestones & 74582 & 687 & 0.343 & 17574.6 \\
\hline & Marls & 123464 & 687 & 0.033 & 2799.1 \\
\hline & Others & 168973 & 687 & 0.014 & 1625.2 \\
\hline & Total & 497477 & 687 & - & 28728.2 \\
\hline \multirow[t]{7}{*}{ Portugal } & Alluvials & 12485 & 882 & 0.083 & 913.9 \\
\hline & Conglomerates & 0 & 882 & 0.056 & 0 \\
\hline & Sandstones & 13516 & 882 & 0.073 & 870.24 \\
\hline & Limestones & 5500 & 882 & 0.343 & 1663.8 \\
\hline & Marls & 1678 & 882 & 0.033 & 48.83 \\
\hline & Others & 56720 & 882 & 0.014 & 700.37 \\
\hline & Total & 89898 & 882 & - & 4197.14 \\
\hline \multirow[t]{7}{*}{ Ireland } & Alluvials & 3384 & 1150 & 0.083 & 323 \\
\hline & Conglomerates & 0 & 1150 & 0.056 & 0 \\
\hline & Sandstones & 11758 & 1150 & 0.073 & 987.1 \\
\hline & Limestones & 24446 & 1150 & 0.343 & 9642.7 \\
\hline & Marls & 0 & 1150 & 0.033 & 0 \\
\hline & Others & 29989 & 1150 & 0.014 & 482.8 \\
\hline & Total & 69577 & 1150 & - & 11435.6 \\
\hline \multirow[t]{8}{*}{ Italy } & Alluvials & 80722 & 982 & 0.083 & 6579.3 \\
\hline & Conglomerates & 0 & 982 & 0.056 & 0 \\
\hline & Sandstones & 31812 & 982 & 0.073 & 2280.4 \\
\hline & Limestones & 71911 & 982 & 0.343 & 24421.5 \\
\hline & Marls & 59212 & 982 & 0.033 & 1918.8 \\
\hline & Others & 41204 & 982 & 0.014 & 566.48 \\
\hline & volcanics & 17694 & 982 & $0.2^{*}$ & 3539 \\
\hline & Total & 302557 & 982 & - & 39305.5 \\
\hline
\end{tabular}

HESSD

$8,4753-4788,2011$

Calculating the average natural recharge in large areas

E. Sanz et al.

Title Page

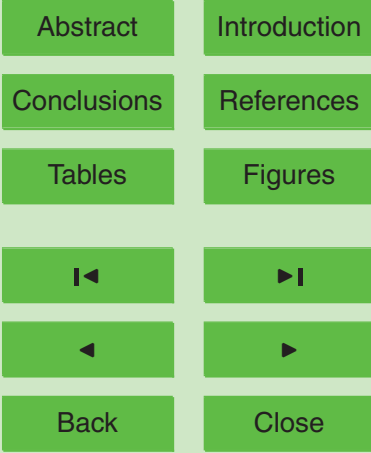

Full Screen / Esc

Printer-friendly Version

Interactive Discussion 


\section{HESSD}

8, 4753-4788, 2011

Table 10. Comparison of estimated mean recharge in earlier published works, and in the present study, for Spain, Portugal, Ireland and Italy.

\begin{tabular}{lrrrr}
\hline Country & Area $\left(\mathrm{km}^{2}\right)$ & $\begin{array}{r}\text { Mean } \\
\text { Precipitation } \\
\text { in } \mathrm{mm} \mathrm{yr}^{-1}\end{array}$ & $\begin{array}{r}\text { Mean Recharge } \\
\text { Previous } \\
\text { works }\end{array}$ & $\begin{array}{r}\text { Estimations } \\
\text { of this work }\end{array}$ \\
\hline Spain (peninsular) & 497477 & 687 & $28908^{1}$ & 28728.2 \\
Portugal & 89898 & 882 & $4000^{2}$ & 4197.14 \\
Ireland & 69577 & 1150 & $10800^{3}$ & 11435.6 \\
Italy & 302557 & 982 & $43000^{4}$ & 39305.5 \\
\hline
\end{tabular}

\section{Calculating the average natural recharge in large areas}

E. Sanz et al.

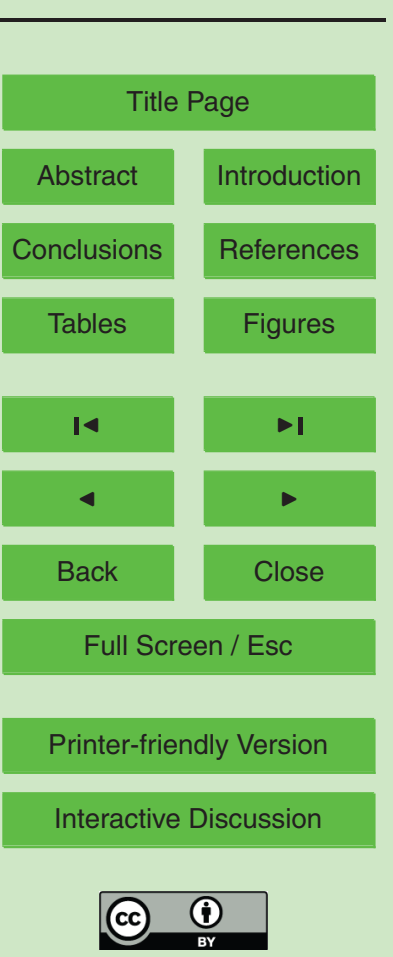

*period 1940/1941-1995/1996

Source: ${ }^{1}$ MIMAM (2000); Estrela et al. (1999). ${ }^{2}$ MIMAM (2000b); Carmona (1999). ${ }^{3}$ MIMAM (2004); EEA (2001); WRI (2001). ${ }^{4}$ MIMAM (2000b); IRSA (1997). 


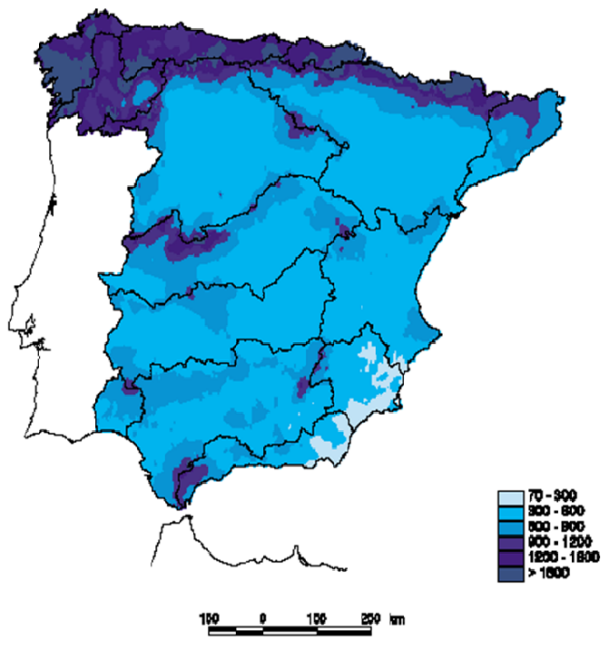

Annual mean precipitation of Spain $(\mathrm{mm})$

Period 1940 - 1960

Ref. MIMAM, 2000

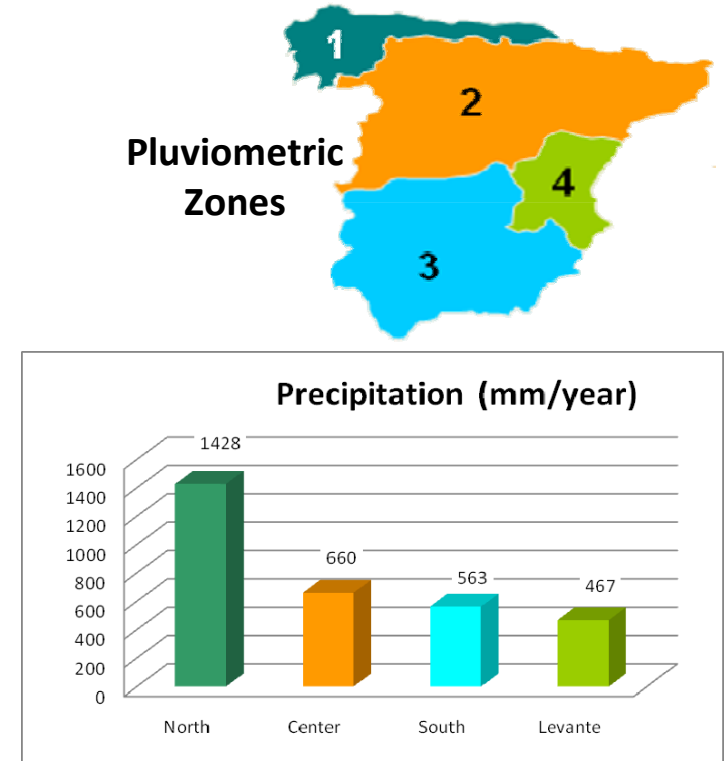

Fig. 1. Pluviometric Zones and Mean precipitation values of Spain.

\section{HESSD}

8, 4753-4788, 2011

\section{Calculating the} average natural recharge in large areas

E. Sanz et al.

\section{Title Page}

\section{Abstract}

Introduction

Conclusions

References

Tables

Figures

14

4

Back

Printer-friendly Version

Interactive Discussion 


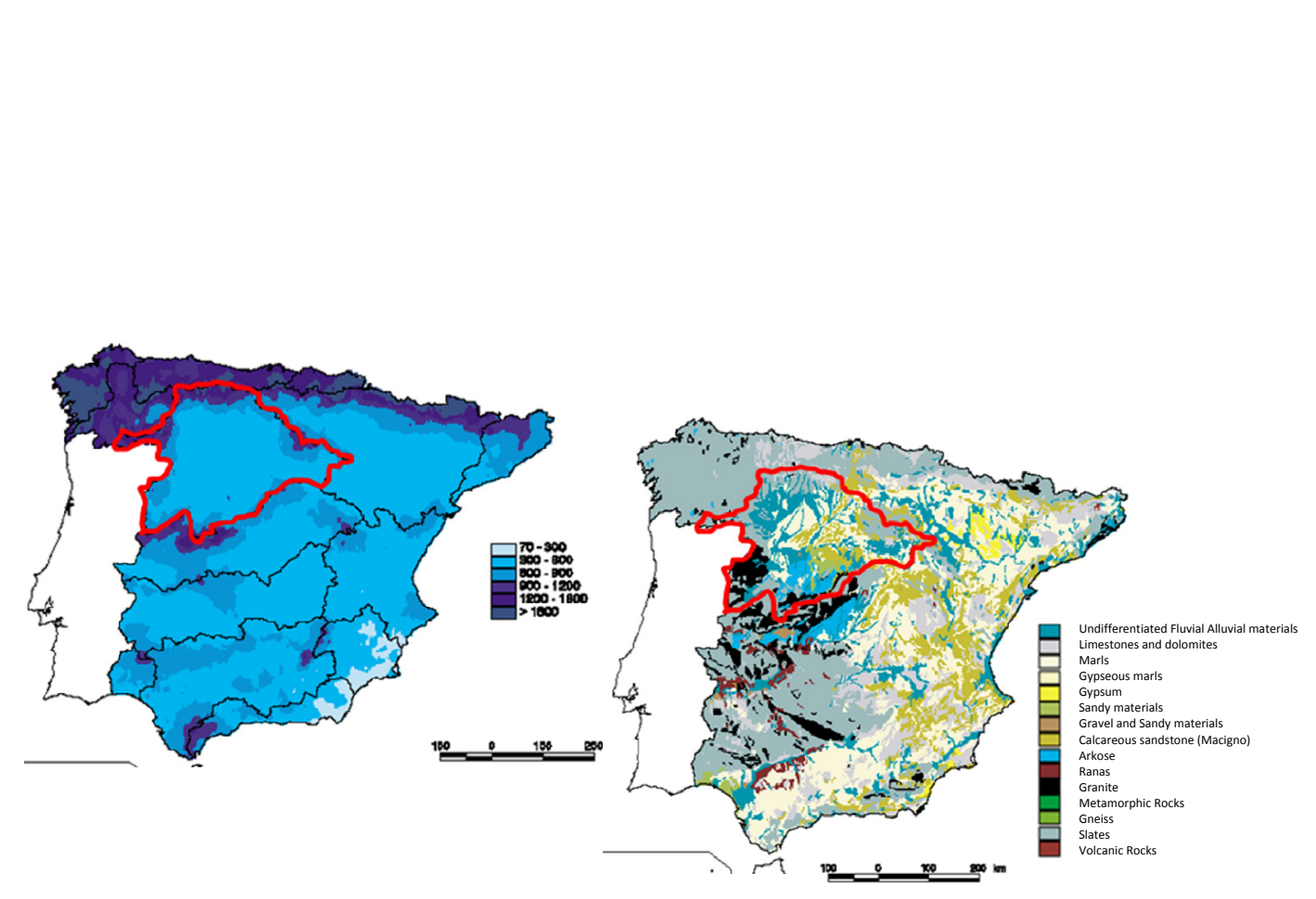

Fig. 2. Lithology Map and precipitation of Duero Basin (Spain). Maps extracted of: MIMAM, 2000 (Spain). Libro Blanco del Agua.

\section{HESSD}

8, 4753-4788, 2011

\section{Calculating the average natural recharge in large areas \\ E. Sanz et al.}

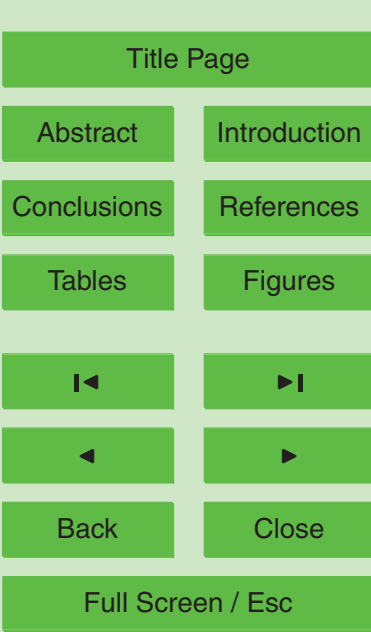

Printer-friendly Version

Interactive Discussion 


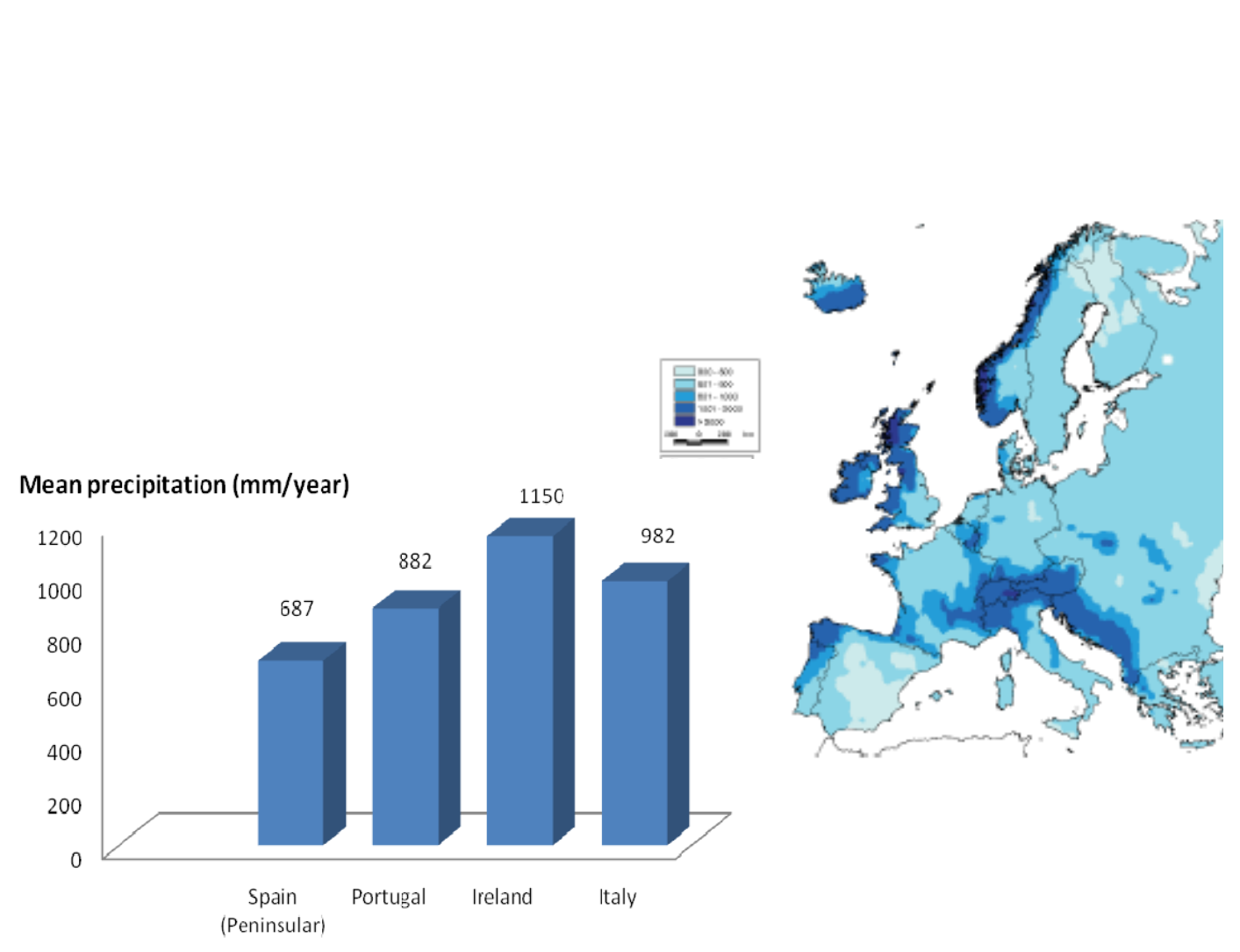

Fig. 3. Annual Mean Precipitation in Europe (mm); period 19940/1941-1995/1996. Source of Map: Extracted of MIMAM, 2004. Aguas Continentales en la Unión Europea (CEDEX).

\section{HESSD}

$8,4753-4788,2011$

\section{Calculating the} average natural recharge in large areas

E. Sanz et al.

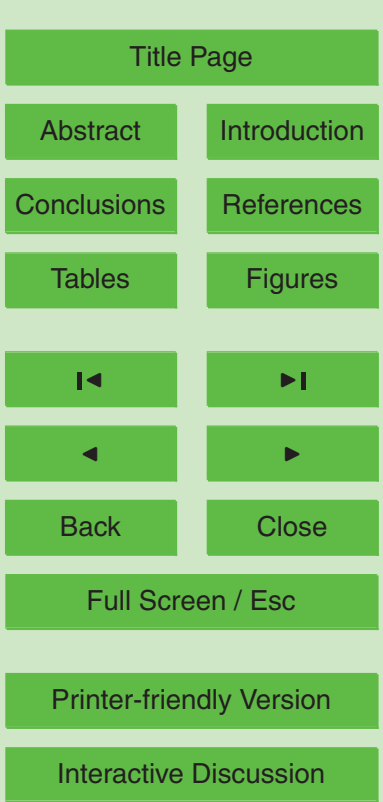




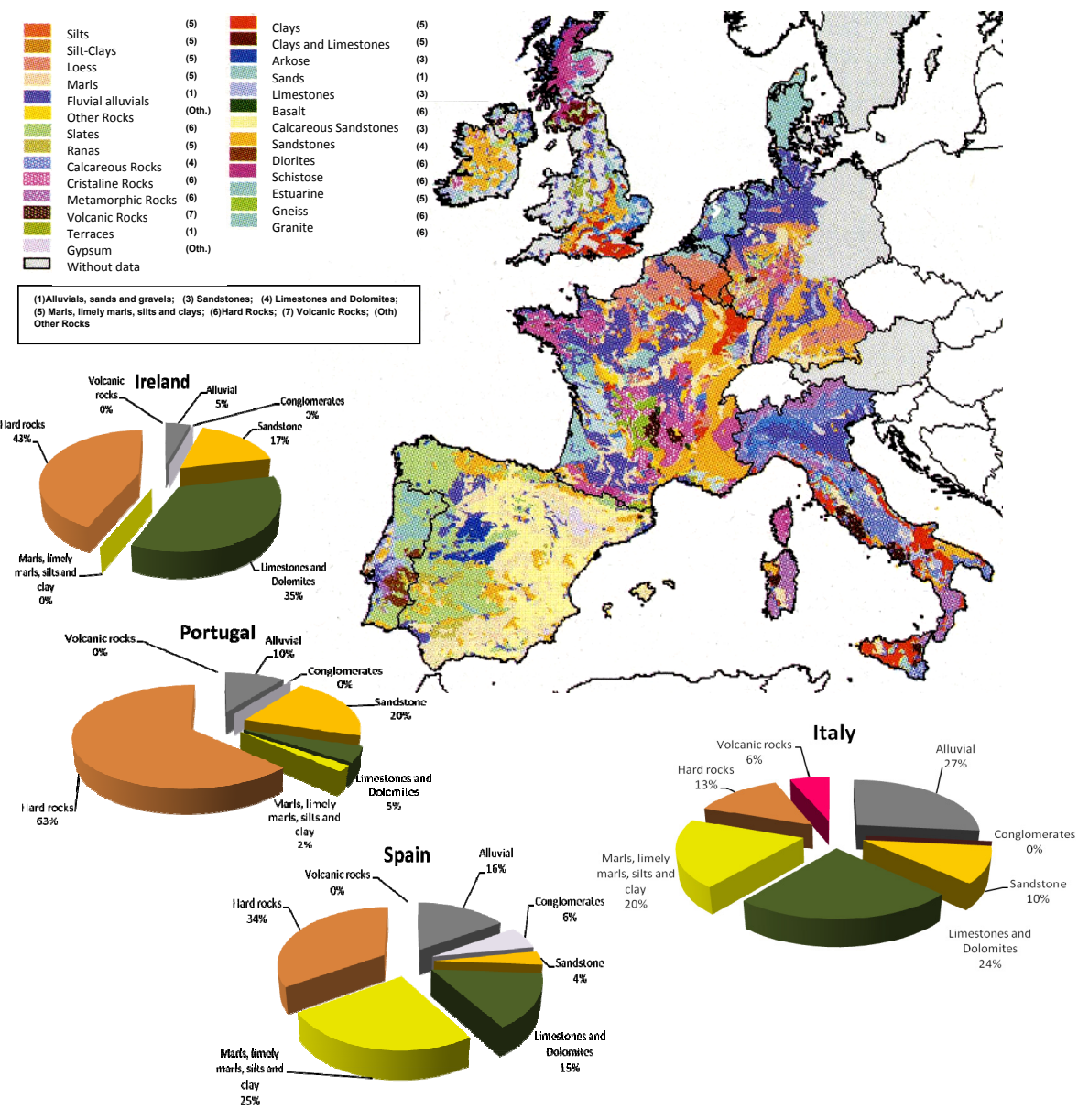

HESSD

$8,4753-4788,2011$

\section{Calculating the average natural recharge in large areas \\ E. Sanz et al.}

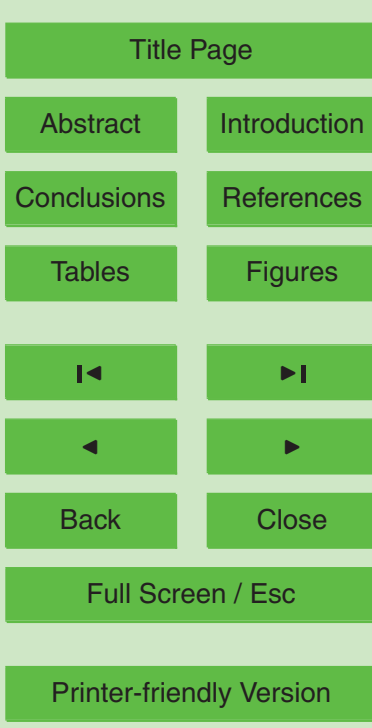

Fig. 4. Lithology Map of Europe and Lithological groups for some European countries. Map extracted of: MIMAM, 2004. Las aguas continentales en la Unión Europea (CEDEX).

Interactive Discussion 